\title{
Place Deixis and the Schematics of Imagined Space: Milton to Keats
}

\author{
Mark J. Bruhn \\ English, Regis University
}

\begin{abstract}
The infrequent, indefinite, and cumulatively incoherent use of place deixis in the representation even of conceptually unified space is characteristic of the greater English lyric from Milton through the eighteenth century. In these poems, as Balz Engler has suggested, such deixis typically operates for the rhetorical sequencing of entities conceived as themes, rather than for the grounding and interrelation of entities conceived as objects within a represented scene. With the advent of romanticism, however, place deixis begins to appear with greater frequency, density, and variety, to trifold effect. It consolidates the represented scene, collapses that scene with the situation-of-discourse, and thereby reorients lyric attention to the local, relative, and embodied. Adapting recent arguments in spatial cognition and cognitive grammar, this study first describes the general functions of place-deictic schemata in literary cognition and then analyzes their poetic fortunes in relation to the concept of lyric sublimity from Milton to Keats.
\end{abstract}

\section{The Schemata of Place Deixis: Proximal-Distal, Relative, Corporeal}

Where there is no shared perceptual, interpersonal, or memorial field of reference-as is almost always the case for discourse encounters between writers and readers of literature-deixis must be construed with ref-

I am deeply indebted to the referees and especially the editor of Poetics Today for thoughtful critique of an earlier version of this argument and generous guidance toward its development and refinement. Remaining faults are entirely my own, but for any strengths I gratefully acknowledge their invaluable assistance.

Poetics Today 26:3 (Fall 2005). Copyright (C) 2005 by the Porter Institute for Poetics and Semiotics. 
erence to conceptual-linguistic schemata rather than any extralinguistic spatiotemporal and psychosocial dimensions of the immediate situationof-utterance or -reception. This reanalysis of prototypical deictic functions underwrites a surprisingly large and vital set of literary effects, appertaining to everything from character, setting, and action within the represented world to sequence, perspective, and evaluation outside of that world, in the representing discourse itself. Obviously, I cannot treat the whole repertory of such effects here; I aim more modestly, first, to provide an analysis of the relative, proximal, and corporeal schemata that structure the semantics of place deixis in literary discourse and representation; and, second, to chart with as much historical, generic, and individual differentiation as possible the development in the use and functions of place deixis in English poetry from Milton to Keats.

The theoretical issues stand in strongest relief (for reasons which will subsequently emerge) at the latter end of this history. Here, for example, is one of Keats's remarkable last poems, in which the situation-of-discourse and the represented situation are marvelously confounded through deixis:

This living hand, now warm and capable

Of earnest grasping, would, if it were cold

And in the icy silence of the tomb,

So haunt thy days and chill thy dreaming nights

That thou would wish thine own heart dry of blood,

So in $m y$ veins red life might stream again,

And thou be conscience-calm'd. See, here it is-

I hold it towards you.

("This living hand, now warm and capable" $1-8)^{1}$

Before any analysis, simply consider the difference made if the poem's optional deictics are systematically replaced with (comparatively) nondeictic alternatives. ${ }^{2}$ For example:

His living hand, at the time warm and capable

Of earnest grasping, would, if it were cold

And in the icy silence of the tomb,

So haunt her days and chill her dreaming nights

That she would wish her own heart dry of blood,

1. I have italicized only venerable kinds of deixis - person, place, and time. Arguments could be made for the speaker- and socio-centric implications of the topic selection and sequencing (see Rauh 1983: 36 and Sternberg 1983) as well as the schematic indexing or grounding of the definite article (an issue to which I will return).

2. Because temporal grounding is criterial for well-formed English clauses, the tenseinflections and modals may be changed but cannot be recast in wholly nonfinite forms. I therefore alter only the present-tense inflections so that they no longer profile the coding time. 
So in his veins red life might stream again,

And she be conscience-calm'd. But it was near-

He held it towards her.

There is a clear difference of orientation, a loss of immediacy, and perhaps a diminished sense of embodiment in the first and final lines-but why? Because the situation-of-discourse, so insistently indexed in the original, is in the revised lines effaced for a more or less exclusive focus on a wholly distinct and distanced scene fabricated by the discourse itself. A comparable differentiation of represented scene and backgrounding of discourse scene may be accomplished by mentally enclosing Keats's lines in quotation marks and hearing them as spoken by one explicitly fictional character to another. ${ }^{3}$

But this is not the poem we have. The strange power of the one we do is generated by Keats's use of deixis to foreground the situation-of-discourse as the represented situation and thereby to precipitate an unsettling recognition of the spatiotemporal and ontological asymmetries that structure the always-operative but often well-masked interrelations between the two levels. ${ }^{4}$ As Balz Engler (1987: 71) has observed, the poem's insistent first- and second-person pronouns and the imperative verb "See" exert "considerable pressure" on us "to take on the role of the implied addressee," but doing so only brings to view the "conflict" between "our own situation as recipients" and "that of the addressee in the text." This sense of incommensurateness between our factual being and our fictional role-playing is further aggravated by the no-more-tractable ontic uncertainties concerning the speaker on the other side of the discourse equation. A lack of alternative specification, knowledge of Keats's impending death at the time of composition, and the potential autographical implication of "hand" all conspire to keep open and alive the possibility that the discourse's fictional encoder is none other than its actual author. But on this reading, the poem's time and place deictics are suddenly forced into Janus-like double duty in reference to the radically disjunctive but propositionally simultaneous and contiguous locations in which the discourse was encoded by "I" and is being decoded by "you." The uncanny collapse of space-time that seems about to be realized in the handshake on offer at the poem's conclusion is structurally redupli-

\section{As we tend to do, for example, with John Donne's "The Flea."}

4. See Lachman (2001: 105, 107) for a discussion of related effects in Keats's narrative poems, which frequently deploy "the spatio-temporal resources of language in order to underline the conflict between an immobile mimetic object and the temporality inherent in its mediation"; the strategy "not only undermines mimesis by displacing the reader's interest from the event to its staging (and consequently to its perception and reconstruction), but . . . it also makes the reader hesitate between different ontological levels." 
cated in the very sequence of the discourse, in which the future (from the speaker's point of view) and the past (from the reader's point of view) are literally contained within the framing "now" and "here" of the (impossible) discourse event. ${ }^{5}$

Engler's (ibid.: 71-72) conclusion that in cases such as this "the deictics no longer tie the text to the situation[s] in which it is used, but, having quasimagical force, create a situation of their own in the imagination" begs yet again the very questions it would answer. What is the nature of this imaginary situation, and by what processes created, if not those indexical and ontological ones we have been tracking?

As I asserted at the outset, the answer has to do with conceptual-linguistic schemata that are applied online (and in routine reading more or less unreflectively) in the processing (decoding) of literary discourse. The three individually scalable and mutually relatable schemata I'll be treating here are all involved in (the construal of) the extraordinary first and final gestures of Keats's poem: "This living hand, now warm and capable / Of earnest grasping"; "See, here it is - / I hold it towards you." The opening demonstrative invokes the proximal-distal schema underlying all place deixis, ${ }^{6}$ and immediately the profiled proximal field is specified by the noun being determined ("hand") as extending somewhere in the neighborhood of an arm's length.

Conceptualizing this opening noun phrase in isolation, we would likely choose between two possible reference frames in which to situate and image the proximal field and the two entities or points (speaker and hand) that define it: a relative frame (another place-deictic schema) in which we image the field from a point of view analogous to the speaker's, with the arm and hand extending outward before us; or an intrinsic frame (the default schema for context-free imaging) in which we image both speaker and hand in a search domain that may be scanned from side-to-side and top-to-bottom and in which the proximal field of focus is now located, as it were outwardly or objectively, in a space immediately in front of the speaker. ${ }^{7}$ However, as

5. Cf. Lachman (2001: 98) on a similar effect in Keatsian epos: "Abandoning Milton's cosmic outlook on history, Keats sought a perspective in which the present is conceived as absorbing both past and future."

6. See Rauh 1983: 12-19 and Lenz 2003: viii for arguments that some such "egocentriclocalistic" or "centre-periphery" schema determines all deictic dimensions (place, time, person, social, discourse, evaluative, etc.).

7. For a fuller description of the phenomenology of this distinction, see Ingarden 1973 [1965]: 230-31. Also, it is important to note that the notion of "frame" in either case is wholly metaphorical. As Ingarden (ibid.: 218) argues, "the represented objects . . do not lie isolated and alien alongside one another but, thanks to the manifold ontic connections, unite into a uniform ontic sphere. In doing so they always constitute-quite remarkably-a segment of a still largely undetermined world, which is, however, established with its ontic type and the 
we read through the poem and reach its conclusion, a third possible frame is not only invoked but finally insisted upon, retrospectively canceling the two previous framing options and recasting their contents in its own terms. This is again a relative frame but one whose coordinates have now been reoriented to the second-person role instantiated by the person deixis, a role we more or less irresistibly occupy for imaging purposes. The speaker is now situated directly in front of us within a shared proximal field ("here") of interpersonal extent, ${ }^{8}$ his hand extending through this space and "towards" us, awaiting our own "earnest grasp."

This last phrase invokes the third schema I'll be analyzing and tracking, that of embodiment or corporeality. Especially because of the various kinds of lexical support-the first-order, anatomical entities "hand," "heart," "blood," "veins"; the haptic images of "warm," "cold," "icy," and "chill"; the kinesthetic invitations of "grasping," "stream," and especially "towards" - we will not only conceptualize but very likely even seem to feel our own undesignated but clearly implicated hand reaching up and out in mirror-image response to the speaker's final gesture. The corporeal effect is here, as elsewhere in Keats's verse, powerfully pronounced, ${ }^{9}$ but the schema supporting it becomes available whenever place deixis establishes any degree of proximal focus and specification within a relative frame of reference.

This last bit of analysis may raise the question as to how and why deictic schemata should be distinguished from other sorts of lexical schemata that do similar work (e.g., amplifying the illusion of corporeality). Obviously, in literary discourse, in which context is neither immediate nor obvious but always constructed and construed, deictic schemata attain referential specificity and bearing only in cooperation with other linguistic schemata (grammatical, lexical, generic, etc.). This inevitable condition places no limit on versatility or productivity; on the contrary, given the wealth of schematic resources available for different kinds of coupling (tripling, quadrupling, etc.), the constraint of codetermination is a motive for endless artistic speculation and experimentation.

That being said, the distinction of deictic schemata from other kinds remains necessary, if only to see the special forms of deviance they make available to the verbal artist. Broadly conceived as a set of grounding func-

type of its essence, that is, a segment whose boundaries are never sharply drawn. It is always as if a beam of light were illuminating a part of a region, the remainder of which disappears in an indeterminate cloud but is still there in its indeterminacy."

8. See Sternberg 1983: 285 on "shared orientational subjectivity" or "the charmed logocentric circle."

9. The best recent discussions of Keats's "unprecedented poetics of embodied cognition" may be found in Richardson 2001: 116ff. and Abrams 1998. 
tions (including the obligatory ones of nominalization and verb inflection), deixis establishes and modulates the "coordination of reference" (Brisard 2002: xvi) between encoder and decoder vis-à-vis the themes, entities, and/ or world(s) being represented. Even in the canonical situation of speech, deixis works primarily to support "subjective construal rather than an objective focus within the scene that is being described" (ibid.: xxix). But in fulfilling the epistemic function of grounding lexical heads or themes (i.e., nouns and verbs) for mutual reference, deictic elements typically background their own operations:

In accordance with their highly grammatical status, grounding predications always constitute the final step in the formation of contextually transparent (if not always totally unequivocal) utterances. They do this by relating a designatum, defined as the profile or point of focal interest within a given predication, to (an element) of the ground without, importantly, having this relation itself be profiled. (Ibid.: xiv)

In other words, deixis points the other lexical categories selected in an utterance (its designata) to their intended referential targets (the ground), but the act of pointing itself is, if you will pardon the pun, not the point. In face-to-face conversation, for example, the demonstrative in the utterance "This object is heavy" would serve "transparently" to ground or specify the lexeme "object" in terms of some perceptually obvious thing, without in any way foregrounding the proximal-distal schema underwriting its act of reference. ${ }^{10}$ But the same utterance delivered at increasing removes from the hearer's/reader's immediate perceptual field (e.g., from another room, on the telephone, on a postcard, as the opening of a poem or novel, etc.) becomes more and more difficult to construe, and the question "What object?" is cognitively reframed, whether momentarily or (as in the Keats poem above) perpetually, as the more primitive question "Where?" In these cases where the search space must be mentally (re)constructed, the proximal-distal schema that operates "transparently" in the face-to-face situation is, to varying degrees but of necessity, "mentally profiled." In general, the more indeterminate the ground of a given discourse, the more deviant and therefore salient its deictics will be.

This principle does not hold, at least not in the same way, for other lexical classes nor even for the definite article, which, insofar as it too per-

10. Thus Langacker (2002 [1994]: 29-30): "The demonstrative this . . does not profile the relationship of identification and of proximity to the speaker, despite their importance to its meaning; what this actually designates - its conceptual referent-is the thing related to the ground in this fashion. The 'on-stage' profile (or referent) of this is consequently a schematically characterized thing (typically specified by the head noun), whereas the ground and the grounding relationship are 'offstage' and unprofiled." 
forms a grounding function, may be counted as deictic. Ronald Langacker (2002 [1994]: 33), who does count it this way, nevertheless acknowledges its "weaker ... directive force, for it carries the supposition that the intended referent is contextually unique, so seeking it out requires no effort." ${ }^{11}$ Compare as context-indeterminate utterances "The hat was purple" and "This hat was purple": the latter is semantically richer not only in terms of its propositional entailments (because it definitely asserts that the hat is no longer purple) but also, and palpably, in terms of its present and proximal spatiotemporal entailments, schematically derived through deixis. As Langacker (ibid.: 34 ) and others have recognized, this is essentially a matter of semantic marking: "there are reasons for believing that distal forms are unmarked relative to proximal ones," chief among which is the fact that in English, as in many languages, "it is . . the distal demonstratives that undergo further grammaticalization to yield semantically weaker forms such as definite articles and subordinators (e.g., English that)." Stephen Levinson (1983: 83, summarizing John Lyons 1977: 653-54), makes the same point: "Lyons suggests that this $x$ retains a pronominal element, as well as containing an adverbial element similar to here. On this analysis, the $x$ differs from this $x$ and that $x$ only in that this $x$ is marked '+ proximal', that $x$ is marked '-proximal', and the $x$ is unmarked for proximity, i.e., it is a neutral deictic term ..." ${ }^{12}$ (This is not to say that the definite article can never assert a deictic proximal schema; it can and does in specific contexts in which the proximal-distal schema has already been activated through other means. See the discussion of Wordsworth's "A Night-Piece," below.)

Place deixis is noteworthy not only for its proximal-distal implications but also, as suggested above, for its determination of the frame of reference in which mental imaging will transpire during literary cognition. Here again, there is an important unmarked/marked distinction to be drawn, in the case of English between a deictically neutral default position, the intrinsic frame of reference, and a deictically specified and profiled position, the relative frame of reference. The literature on reference frames is vast but technically various and as a result often confusing; the clearest and most experimentally comprehensive discussion I know of is Levinson's Space in Language and Cognition: Explorations in Cognitive Diversity (2003). Levinson (ibid.: 76) proposes a tripartite typology of spatial reference frames that is variously realized and expressed across human languages: "the intrinsic system [or frame], which projects out a search domain from a named facet of

11. See also Lyons (1977: 654, 657), who likewise analyzes "definite referring noun-phrases" as "always contain[ing] a deictic element" but allows that it tends to be used and construed in "deictically neutral" ways.

12. Rauh (1983: 52) gives a complete semantic feature analysis of this difference. 
a landmark object; the relative system, which imports the observer's bodily axes and maps them onto the ground object, thus deriving named angles; and the absolute system, which uses a fixed set of bearings or a conceptual 'slope' to define a direction from a ground object." Intrinsic systems are, as far as we know, operative in all natural languages, and in all (doubtless because of our upright stance) an absolute system informs the conceptualization of verticality (ibid.: 314). But beyond this it appears that a given language will promote either a relative system or an absolute system, to the detriment of the other and as it were unselected system, which remains underdeveloped and hardly used. Speakers of English, for example, like other "relative-language speakers[,] seem to show an almost total absence of absolute coding tendencies" (ibid.: 214). ${ }^{13}$

Of the default intrinsic and (prototypically ${ }^{14}$ ) deictic relative systems that English does employ, Paradise Lost (1667/1674) affords us especially clear and memorable examples. Presenting Satan's first view of the "steep wilderness" that is crowned by "the champaign head" of Eden (4.131-53), Milton describes the intrinsic spatial relations of the constitutive images, using each as a landmark or relatum to locate the next. Thus, we image first the "hairy sides" of the wilderness "With thicket overgrown"; then, "over head" of them, "ranks" of trees, "Cedar, and Pine, and Fir, and branching Palm," "Shade above shade"; next, "higher than thir tops / The verdurous wall of Paradise" appears, and still "higher than that Wall a circling row / Of goodliest Trees loaden with fairest Fruit." We have no particular point of view on the composite image; for example, the "sides" of the wilderness have no left and right or front or back determinations, and our angle of vision is equally unspecified and immaterial. Milton's metaphors for the "Silvan Scene" he has depicted are particularly revealing in this respect: it is now a "Theatre / Of stateliest view," now a "Lantskip," two figures that imply a distanced and framed search domain that may be scanned from multiple angles without significantly transforming the spatial relations represented or foregrounding (profiling) any literal point of view. ${ }^{15}$ Roman

13. This is not to say we never use absolute systems - we do (for example, every time we compute cardinal directions), but only through conscious effort rather than automatic dead reckoning. See Werner et al. 1998: 112ff. for a review and discussion of experimental data illustrating this difference.

14. Levinson (2003: 43) discusses nondeictic deployments of the relative frame but concludes, "Nevertheless, there can be little doubt that the deictic uses of this system are basic (prototypical), and are ontogenetically and conceptually prior."

15. In terms of the phenomenological experience of spatiality, the viewer's embodied viewpoint is, according to Merleau-Ponty (2004: 104), "the third term, always tacitly understood, in the figure-background structure, and every figure stands out against the double horizon of external and bodily space." 
Ingarden's (1973 [1965]: 232) comments on the peculiar conceptualization involved when one reads a dramatic text, rather than seeing it performed, are applicable here. The reader's "center of orientation" is that of a "possible spectator" who is neither "really present in [the] dramatic work" nor like "one of a number of real spectators who would be present at [its] performance." "Quite on the contrary," Ingarden continues, "here the invisible spectator belongs to the represented world, with the difference that he does not attain explicit representation."

When place deixis comes into play in particular densities, however, it determines a relative frame of reference that further specifies the spectator's position within the represented world and locates objects with reference to that now explicitly represented position. Semantically, we should say then that, in English as in all "relative languages," the intrinsic frame is unmarked, the relative frame marked: this may be inferred from Levinson's (2003: 314) proposed linguistic universal stating that "a relative frame of reference implies an intrinsic one." In a more speculative treatment of frames of reference concepts, the philosopher John Campbell (1993: 72) outlines the same position in slightly different terms: "The definition of an egocentric $\left[\right.$ relative $\left.{ }^{16}\right]$ frame as a body-centred frame takes for granted the general notion of an object-centred [intrinsic] frame of reference, and says that the egocentric frames are a particular class of object-centred frame, namely those which are centred on the body or a part of the body." In a relative frame, an entity is still located in space in relation to another entity, as it is in an intrinsic frame, only in this case the latter or landmark entity is a (more or less) profiled representation of the spectator or viewpoint within the frame instead of outside and in front of it. ${ }^{17}$ A most remarkable instance

16. Sternberg (1983: 284) rightly rejects as misleading the label "egocentric" for deictically determined frames: "In normal face-to-face communication ... [the speaker] shares the hereand-now with the addressee, and so must in principle orient himself to both in translating objective facts into subjective speech. And even where finer distinctions along the proximaldistal line come in, he will often postulate the addressee's rather than his own time or place as the centre of deictic reference, by a self-distancing process [Charles] Fillmore calls 'taking the other fellow's point of view'. .. . In short, the speaker maps the world onto the spatiotemporal coordinates of the act of utterance, exploiting some of the orientational features to ally himself with his fellow participant and others (including subdivisions of the same) to qualify or shift the zero-point [of the coordinate system] according to the resources of deixis and the rhetoric of discourse."

17. Thus, Levinson (2003: 71) advises that "[it] is important to appreciate that deixis itself does not constitute a frame of reference. That is because deictic specifications of location merely use the deictic centre as a special kind of ground . . . we need to make a clear distinction between the nature of the coordinate system itself - whether, for example, it is based on bodily coordinates or fixed bearings - and the nature of the origin of the coordinate system: the origin of any frame of reference can, but need not be, a participant in the current speech event." 
of this kind of framing occurs in Uriel's speech to the disguised Satan in Paradise Lost, as the two stand upon the sun and gaze out upon our solar system:

Look downward on that Globe whose hither side

With light from hence, though but reflected, shines;

That place is Earth the seat of Man, that light

His day, which else as th'other Hemisphere

Night would invade, but there the neighboring Moon

(So call that opposite fair Star) her aid

Timely interposes, and her monthly round

Still ending, still renewing through mid Heav'n,

With borrow'd light her countenance triform

Hence fills and empties to enlighten the Earth,

And in her pale dominion checks the night.

That spot to which I point is Paradise,

Adam's abode, those lofty shades his Bow'r.

Thy way thou canst not miss, me mine requires.

$$
(3.722-35)^{18}
$$

Notice how much about the spectator's position is determined here that remains undetermined in Milton's subsequent description of the steep wilderness rising to Paradise: "downward" renders a specific vertical orientation, the proximal-distal schema of the demonstratives and the locatives "hence" and "other" gives a measured depth or length perspective, while the locatives "there" and "opposite" appear to designate a point (the moon) that must be more or less explicitly imaged as lying to the left or right of earth on the horizontal axis of width. The passage thus perfectly illustrates Campbell's (1993: 74) proposal that "an egocentric [or relative] frame is one defined by the axes 'up,' 'down,' 'left,' 'right,' 'in front,' and 'behind,' with the origin identified as 'here.'”

These schematic directional categories have their epistemic foundation in embodied perception, ${ }^{19}$ and that brings us round again to the third place-

18. Henceforth, unless otherwise noted, I will italicize only place deictics in poetic quotations; to avoid confusion, I will silently remove italics on nouns, proper names, etc., that, solely for reasons of typographic convention, appear in the originals.

19. For an interesting developmental account of why this should be so, see Tracy (1983: 10910), who argues that our sensorimotor knowledge for action in space is itself "essentially indexical." Indexical language or deixis is thus able more or less readily to evoke the associated (and normally integrated) schemata of visual, auditory, haptic, and kinesthetic perception. Werner et al. (1998: 111), summarizing O. J. Grusser's findings on the "multimodal structure of extrapersonal space," argue for the division of mental space representations into "four basic units": "grasping space," "near-distant action space," "far-distant action space," and "visual background." At each step along this series, fewer sensorimotor modalities are implicated in perception, grasping space being fully embodied and near-distant space poten- 
deictic schema identified above in addition to the proximal-distal and relative ones. The corporeal schema is the most optional and variable of the three because in most cases it depends for its activation on the degree of specificity with which the other two are invoked and realized. As Campbell (ibid.) speculates about the egocentric perception of space in general,

it does not seem that a subject needs to have a body-image in order to be capable of egocentric spatial action ... The co-ordination and direction of spatial action may be achieved by purely distal specifications of the locations which are the endpoints of the actions, without the subject having a single central body-image at all . . . If a body-image is superimposed on the subject egocentric axes, that is additional to the requirements for it to be thinking about places egocentrically. So when the subject is identifying places egocentrically, it cannot be thought of as doing so by first identifying a physical thing - itself-through a body image, and then identifying places by their relation to its body. Rather, its capacity to use the egocentric axes is more fundamental than its capacity to think in terms of body-image. ${ }^{20}$

Certainly in verbal-conceptual representations involving an egocentric or relative frame, "distal specifications" alone are less likely to invoke the subject's or representer's body image as a perceptible part of the mental representation. Thus, in terms of degrees of the reader's/viewer's (implicated) embodiment within a relative frame, the difference between Keats's lines representing "this living hand ..." and Milton's/Uriel's lines representing the position of earth in space has everything to do with the specific contraction, delimitation, and profiling of the proximal field in the one and the general indetermination, potential extent, and unprofiled nature of the proximal field in the other. ${ }^{21}$

tially so, while far-distant space is typically registered only by "visual and auditory cues" and the background solely by visual cues that are "undifferentiated with respect to depth cues." 20. Campell (1993: 75) further observes that these axes are more or less isomorphic with "the natural axes of the body." The depth or length axis exploits the front/behind distinction expressed in and conceptually derived from a physical asymmetry of the body; the vertical axis is structured in relation to the up/down gravitational orientation of that body; but the horizontal axis of left/right or width "does not have anything especially to do with the bodily axes at all. It is not ... that there is any bodily asymmetry that the distinction labels, since animals are generally right/left symmetric. Nor does it, like 'up' and 'down', label some external physical magnitude which is of general importance for action."

21. Merleau-Ponty (2004: 106) likewise understands the proximal-distal distinction to be at the root of the embodied phenomenological perception of space: "the point-horizon structure is the foundation of space. The horizon or background would not extend beyond the figure or round about it, unless they partook of the same kind of being as the figure, and unless they could be converted to points by a transference of the gaze. But the point-horizon structure can teach me what a point is only in virtue of the maintenance of a hither zone of corporeality from which to be seen, and round about it indeterminate horizons which are the counterpart of this seeing." 


\section{The Advent of Place (Deixis) in the Greater English Lyric}

As it happens, this theoretical distinction exemplified by single instances of Miltonic and Keatsian representation can be broadly restated in generic and historical terms, an enterprise to which we are now prepared to turn. In order to highlight individual choice and historical difference, the ensuing discussion will focus on lyric rather than dramatic or narrative genres. Especially in literary discourse, as Keith Green (1992: 125) has observed, where referential context is always to be determined, genre provides an important "pragmatic frame governing sense-making operations" for the interpretation of deixis. Dramatic discourse, which imitates the canonical situation of speech, that is, face-to-face dialogue in perceptible contexts, routinely incorporates place deictics and always implies (and through stage directions often specifies) some more or less determinate ground to which they are supposed to refer. When read with any awareness of its implicit and potential relation to the performance space of a stage, the deixis in dramatic discourse will tend to be construed, as Ingarden (1973 [1965]: 232) suggests in the passage quoted above, within an intrinsic frame of reference that has no specific locative, orientational, or corporeal implications for the reader. When heard in performance, place deixis becomes even more "transparent" or less profiled, now functioning perceptibly and unambiguously in terms of axial fields centered on the performers' bodies within the even more obviously intrinsic spatial frame of the actual stage. ${ }^{22}$ Typical functions of place deixis in the discourse of narrative genres range from an explicitly dialogic operation similar to that of dramatic discourse (i.e., where characters are represented as conversing and indexing their shared situation-of-utterance) to an (often "transparent" or unprofiled) ontic one that characterizes the narrator and indexes his or her relation to the represented situation and/or the situation-of-discourse. ${ }^{23}$ Lyric discourses may be said to radicalize and profile the functions described at the latter end of the narrative spectrum, prototypically by collapsing represented and discourse situations into a single level. In this case, there is no compulsion to explicitly render (e.g., through stage directions or "objective" description) the represented situation, because it is (assumed to be) immediately available as the situation-of-discourse. ${ }^{24}$ It is this fiction, of course, which runs

22. Herman (1997) provides a general theoretical account of place deixis in drama, Gillies (2001) a historically specific one about the operations of such deixis in English Renaissance drama, especially Shakespeare's.

23. For a range of related approaches to narrative uses of deixis drawn from the pages of this very journal, see Johnson 1982 (on thematic aspects); Sternberg 1990: esp. 941-44, 1992: esp. 534 (on temporal issues); and Herman 1999 (on epistolary applications). On the various roles of deixis in structuring the discourse sequence, see Sternberg 1981, 1983.

24. For this reason, as Green (1992: 124) notes, "lyric poetry" would seem to be "the genre 
headlong into the reality of the situation-of-reception, to astonishing effect, in the brief Keats poem I examined at the outset of the article.

Such effects are notably rare in pre-romantic lyric poetry and virtually nonexistent in its major subtypes, including the country-house poem, georgic, pastoral, ode, verse epistle, and loco-descriptive or prospect poem..$^{25}$ In the main tradition of these forms from Milton and Denham to Pope and Thomson to Collins and (excepting his "Elegy") Gray, place deixis, when it appears at all, tends to be so generalized in its use as to have no effect in terms of frame selection, proximal-distal specification, or, as a consequence, embodiment. For example, the few instances of place deixis in Milton's "Nativity" and unfinished "Passion" odes function principally to establish a very general thematic (rather than spatially imaged) contrast between earth and heaven, "here" and "there"; in Lycidas, as in L'Allegro and Il Penseroso, they additionally serve to summon ("come") mythical, religious, and allegorical figures to, and dismiss ("hence") them from, an otherwise indeterminate scene. Whenever Milton seems in these poems to be implicating and activating latent place-deictic schemata, other immediate features undermine their operations and prevent their mutual reinforcement along the sequence of a spatially coherent scene.

Consider the following stanzas of Milton's "The Passion" (1630), which contain about as many potentially place-deictic terms in a comparable span of lines as you'll find anywhere in Milton's lyric verse. I have also emphasized person and optional time deictics, so as not to neglect their potential spatial effects:

See, see the Chariot and those rushing wheels

That whirl'd the Prophet up at Chebar flood;

My spirit some transporting Cherub feels,

To bear $m e$ where the Towers of Salem stood,

least likely to assist us" in the exploration of literary deixis. In fact, as my argument claims, the more difficult it is to construe deixis, the more foregrounded and salient its operations. Lyric genres may thus prove especially useful for identifying and studying those operations. 25. By "major" I mean more prestigious in the hierarchy of genre than other lyric forms, such as the epigram, sonnet, song, and occasional poem. Abrams (1984) calls these major subtypes "the greater lyric," and Sheats (1990: 179) gives a useful summary of their generic qualities in terms of the eighteenth-century "greater ode": "an elevated diction, forceful prosodic variation, a reflexive decorum ... in which the poet comments on his poem and its difficulty, and, finally, the sublime vision itself. Presented explicitly to the eye, this vision in later strophes addresses matter of grave and national importance and indeed presumes to articulate the conscience of England." These qualities in differing combinations characterize not only the ode, but also such diverse "greater lyrics" as Milton's Lycidas, Pope's Windsor Forest, Thomson's The Seasons, Dyer's Grongar Hill, and even (though much more playfully and problematically because of its simultaneous incorporation of epic conventions) Cowper's The Task. The "prospect" poem is simply another and increasingly current name for the loco-descriptive poem; see, e.g., Heffernan 1984: xix, 9, 10, 14, etc.; Chambers 1996: 38, 97, 101, etc. 
Once glorious Towers, now sunk in guiltless blood;

There doth my soul in holy vision sit, In pensive trance, and anguish, and ecstatic fit.

Mine eye hath found that sad Sepulchral rock

That was the Casket of Heav'n's richest store,

And here though grief $m y$ feeble hands up-lock,

Yet on the soft'ned Quarry would I score

My plaining verse as lively as before;

For sure so well instructed are $m y$ tears,

That they would fitly fall in order'd Characters.

$\left(3^{6-49)}\right.$

The opening imperatives at first appear to implicate a second-person role in tandem with the speaker's first-person role, suggesting that readers are to direct their mental attention to "the Chariot" subsequently indicated and apparently on view in the immediate situation-of-discourse. But the shift in focus two lines later, and especially the unusual deictic collocation "There doth my soul in holy vision sit" only three lines after that, make it clear that the command to envision, to "See, see," is issued by the speaker to himself and in any event is not to be construed in bodily terms. (Presumably, the speaker's body remains in some unprofiled "here" that is discontinuous with the space his "spirit" occupies "There . . . in holy vision.") Also odd is the collocation of definite and demonstrative articles in "the Chariot and those rushing wheels," where we might rather expect either the definite article and a pronoun - "the Chariot and its rushing wheels" - for less-specific and less-profiled grounding or two demonstratives - "that Chariot and those rushing wheels"-for more-specific, more-profiled grounding. Given the relative clause that follows, however, it becomes possible to resolve the incongruity by interpreting the demonstrative article as being primarily discoursal and pointing cataphorically to the subsequent line's lexical (rather than indexical) specification of the chariot and wheels in question. ${ }^{26}$ This interpretation seems the more likely given the shift of focus in the next two lines to the new and indefinite or deictically neutral topics of "some transporting Cherub" and "the Towers of Salem." The latter are conceptually no sooner raised than they are razed by the time deictics ("once," "now") of the subsequent line, then raised again by the essentially anaphoric but nevertheless clearly distal adverb "There" at the outset of the next. How-

26. As a general rule, when a demonstrative pronoun or noun phrase is post-modified, the demonstrative element tends to function more as a discourse deictic than a place or time deictic (though it still retains a proximal or distal signification). This is my one quibble with Green's (1992: 128-33) otherwise unexceptionable analyses of deictics in Vaughan's "The Retreate" and Wordsworth's "Nutting." 
ever sensible thematically, this abrupt instantiation, destruction, and resurrection militate against any very definite spatial imaging of the towers, especially since they are displaced and erased along the sequence as rapidly as Ezekiel's chariot was by them. The opening of the next stanza focuses on a new location, "that sad Sepulchral rock," but the conceptual inconsistency between the distal demonstrative article and the proximal adverb "here," used only two lines later to indicate the same location, shows once again that the speaker does not imagine, nor does the discourse represent, a fixed orientation within a spatially coherent scene. The place-deictic schemata that might have been summoned and integrated by the demonstratives and the spatial adverbs have, instead, been rendered inoperative by their uncertain and often conflicting status with respect to each other and to the other themes and purposes of the passage.

Similarly in L'Allegro (1631), the poem's only approach to definite imaginative stationing is suggested by "the Plowman near at hand," in which "at hand" implies the speaker (person deixis) and thus one point in a proximal search domain (place deixis) that apparently extends into the "near" distance to another point occupied by the Plowman. But this effect is dispelled at once by the ensuing images, which are sequenced not by any located perspective but more or less haphazardly and without further deictic specification:

... the Plowman near at hand

Whistles o'er the Furrow'd Land

And the Milkmaid singeth blithe,

And the Mower whets his scythe,

And every Shepherd tells his tale

Under the Hawthorn in the dale.

Straight mine eye hath caught new pleasures

Whilst the Landscape round it measures,

Russet Lawns and Fallows Gray,

Where the nibbling Flocks do stray;

Mountains on whose barren breast

The laboring clouds do often rest;

Meadows trim with Daisies pied,

Shallow Brooks, and Rivers wide.

Towers and Battlements it sees

Bosom'd high in tufted Trees,

Where perhaps some beauty lies,

The Cynosure of neighboring eyes.

Hard by, a Cottage chimney smokes,

From betwixt two aged Oaks ... 
The auditory images at the outset of the passage cannot be construed as emanating from simultaneously existing points in the speaker's relative frame of reference. They constitute instead an emblematic catalog of rural sounds, as the final image in the series insists. Obviously the shepherds cannot all be telling their tales at once in the same space-time under the same hawthorn (not, at least, without producing a cacophony that would drown out the individual tales as well as the competing sounds of the plowman's whistling, the maid's singing, and the mower's scythe whetting!). The subsequent catalog of visual images is again typical rather than spatially organized or integrated. This is clear not only from the perspectival disorder of the sequence (the series "Lawns" $\rightarrow$ "Mountains" $\rightarrow$ "Meadows" $\rightarrow$ "Brooks, and Rivers" $\rightarrow$ "Towers and Battlements ... / Bosom'd high in tufted Trees" reveals no governing down-to-up, side-to-side, or near-to-far order) but also from the ruling parataxis, which simply juxtaposes entities rather than relating them one to another in logical, landmark-target relations. Only at the very end of the passage does this sort of relation emerge, in the prepositional phrase "hard by," which, given the nondeictic reference and sequencing of all that precedes it, functions in an intrinsic rather than a relative frame to locate the cottage in proximity of the castle but not necessarily of the speaker.

The spatial disarray in this poem and its companion Il Penseroso is all the more noteworthy given the consistency of the apostrophic address ${ }^{27}$ (person deixis) in both poems and the logical progression of the temporal markers (including time deixis) along their sequences, from morning to night in the one and from evening to evening in the other. These potential unities of represented character and time might well consolidate a third of space, but Milton subordinates all three dimensions, and the spatial one especially, to a conceptual dimension that catalogs a wide-ranging variety of mythological, allegorical, and generic themes more in propositional than presentational terms. These thematic imperatives neutralize possibilities of coherent spatial organization and specification, just as they do in Lycidas and the "Nativity" and "Passion" odes and, to similar or only slightly lesser degree, in the bulk of seventeenth- and eighteenth-century English lyric verse, including genres such as the country-house poem and the prospect poem that intrinsically entail a spatially unified scene to be represented, often as the situation-of-discourse itself.

Consider, for example, John Denham's “Cooper's Hill” (1655/1668), a prospect poem Samuel Johnson (1967: 77) praised for inaugurating "a species of composition that may be denominated local poetry, of which ode. 
the fundamental subject is some particular landscape, to be poetically described, with the addition of such embellishments as may be supplied by historical retrospection or incidental meditation." The poem represents successive and spatially contiguous views from the crown of Cooper's Hill, looking out first toward London and St. Paul's in the "distance" (28), then to the plateau and castle of Windsor, then to the "neighboring" (113) St. Anne's Hill, and then, "descending from the Hill" (159), to the river Thames. This progress describes what Meir Sternberg (1981: 81-88) calls a perspectival order, but, in terms of spatial representation, the implied perspective is faintly sketched indeed. Scenic implications, especially of the intermittent place-deictic terms, are profiled just long enough to effect transitions from one to the next of the poem's far more extensively developed and essentially nonspatial themes, which then instantly and exclusively occupy the foreground. Thus, while the poem's first gesture toward represented space apparently encourages a relative frame of reference on a point far distant from the speaker's eye, the lack of any specification of the proximal range prevents that frame from taking hold to organize the imaging and interrelation of focalized entities. Taking "flight" from its station on Cooper's Hill,

My eye ... swift as thought contracts the space

That lyes between, and first salutes the place

Crown'd with that sacred pile, so vast, so high,

That whether 'tis a part of Earth, or sky,

Uncertaine seems, and may be thought a proud

Aspiring mountain, or descending cloud,

Pauls ...

$(13-19)$

Denham figures his instantaneous and extreme extension of the representational space wittily, but also justly, as a contraction, for he collapses the viewpoint into the viewed-point with no representational regard for "the space / That lyes between" (some eighteen miles, in point of fact). The implicit but never-profiled proximal realm simply evaporates, "swift as thought," in deference to the indeterminate vision of the horizon, which (despite the conceits of flight and contraction) nevertheless is not approached but retains its distant, screen-like two-dimensionality. The odd collocation of articles (as in Milton) - "the place / Crown'd with that sacred pile" - and the cataphoric specification of the "pile" as "Pauls" indicate grammatically just how "Uncertaine" the grounding reference of the distal demonstrative really is. Similarly with the ensuing representation of Windor's "gentle height": the topographical "Rise" appears first as the distant "basis of that pompous load" (Windsor Castle) but then, just three lines later, somehow on much nearer view, as "this ground" (45, 49-50, 53). The incon- 
sistent application of the proximal-distal schema (again like Milton) suggests that the speaker references entities with attention not to their spatial relations in the situation-of-discourse but solely to their topical roles in the developing discourse itself.

In the subsequent transition from the theme of Windsor Castle to that of St. Anne's Hill, this discoursal rather than situational interpretation of the deixis can hardly be avoided:

Here should my wonder dwell, and here my praise, But my fixt thought my wandring eye betrays, Viewing a neighboring hill ...

$$
(111-13)
$$

Indexing as it does the same entity earlier termed "that pompous load," "here" is most readily construed as a discourse deictic whose proximal designation refers to a topic near in mind rather than a location close at hand. This construction in turn promotes an intrinsic framing of "neighboring" as describing a spatial relation between the distant hills of Windsor as landmark and St. Anne's as target, as opposed to a relative and potentially embodied framing that would locate St. Anne's in proximity to the speaker standing atop Cooper's Hill. The speaker's stationing literally does not figure, and even the intrinsic localizing of St. Anne's hill serves but as a logical cue for an extended disquisition on Henry VIII's "sacrilegious" destruction of Chertsey Abbey and Chapel, those "dismall heaps" (149) still crowning the hill. This "historical retrospection or incidental meditation" is hardly an "embellishment" upon the "fundamental subject" of "some particular landscape"; structurally speaking, the relationship is, contra Johnson, quite the reverse. Notwithstanding the transitional authority of the wandering eye, the contextually transcendent ideas of "fixt thought," here and throughout the poem, clearly retain the representational and evaluative upper hand. Indeed, the speaker signals this thematic preference for abstract thought over concrete vision from the outset when he contrasts, in terms of limitation, the spacious prospect stretching before him with the "untrac'd waies, and ayrie paths I flye, / More boundlesse in my Fancy than my eye" (11-12).

This premium on boundlessness percolates through the poetry and theory of the eighteenth century, sustaining in English lyric verse a surprisingly widespread lack of interest in the representational values of place deixis. The poetics of boundlessness, greatness, and (ultimately) sublimity ${ }^{28}$

28. For a compact overview of the development of the theory of the sublime in English letters, see Lamb 1997. 
were influentially formulated early in the century by Addison and Steele (1945 [1712], 3:279) in their Spectator papers on the pleasures of imagination:

The Mind of Man naturally hates every thing that looks like a Restraint upon it, and is apt to fancy it self [sic] under a sort of Confinement, when the sight is pent up in a narrow Compass, and shortened on every side by the Neighbourhood of Walls or Mountains. On the contrary, a spacious Horison [sic] is an Image of Liberty, where the eye has Room to range abroad, to expatiate at large on the Immensity of its Views, and to lose it self amidst the Variety of Objects that offer themselves to its Observation. Such wide and undetermined Prospects are as pleasing to the Fancy, as the Speculations of Eternity or Infinitude are to the Understanding.

Almost half a century later, Edmund Burke takes up this idea under the heading of "Vastness," in his Philosophical Enquiry into the Origin of Our Ideas of the Sublime and Beautiful (1990 [1757]: 66): "Greatness of dimension, is a powerful cause of the sublime. This is too evident, and the observation too common, to need any illustration ..." The observation may, however, be refined, Burke continues, in terms of both the perception of extension (width, length, height) and, especially, the illusion of infinity:

Infinity has a tendency to fill the mind with that sort of delightful horror, which is the most genuine effect, and truest test of the sublime. There are scarce any things which can become the object of our senses that are really, and in their own nature infinite. But the eye not being able to perceive the bounds of many things, they seem to be infinite, and they produce the same effects as if they really were so. We are deceived in like manner, if the parts of some large object are so continued to any indefinite number, that the imagination meets no check which may hinder its extending them at pleasure.

Addison and Steele (1945 [1712], 3:282-83) had very similarly argued, though in theological rather than Burke's psychophysical terms, that "the highest pitch of Astonishment and Devotion" obtains "when we contemplate . . . that [which] is neither circumscribed by Time nor Place." ${ }^{29}$

29. For these and most contemporary writers on the subject of the sublime, no English poet had authored more exemplary contemplations in this respect than Milton in Paradise Lost. Thomas Gray, writing in the same year as Burke, extols Milton's unparalleled achievement in his ode "The Progress of Poesy," which itself eschews place-deictic specification or circumscription in order to improve its own belated and cross-generic claims to the sublimity that it celebrates:

Nor second He, that rode sublime

Upon the seraph-wings of Extasy,

The secrets of th'Abyss to spy.

He pass'd the flaming bounds of Place and Time ...

$(95-98)$ 
By the time we reach Shelley's Defence of Poetry (1821), the antispatiotemporal bias of the sublime characterizes not just a particular kind of poetic effect but the very essence of poetic conception in any genre whatever: "A Poet participates in the eternal, the infinite, and the one; as far as relates to his conceptions, time and place and number are not. The grammatical forms which express moods of time, and the differences of persons and the distinctions of place are convertible with respect to the highest poetry without injuring it as poetry" (Shelley 1965, 7:112). Shelley doubtless has deictic "grammatical forms" (among other kinds) in mind; ${ }^{30}$ he allows their temporal, personal, and spatial determinations even in "the highest poetry" (evaluated here not on a generic but on a metaphysical scale) but clearly with an implicit caution against the overspecification of "time and place and number," which would injure the poetry. As he says subsequently in the Defence,

There is this difference between a story and a poem, that a story is a catalogue of detached facts, which have no other connection than time, place, circumstance, cause and effect; the other is the creation of actions according to the unchangeable forms of human nature, as existing in the mind of the creator, which is itself the image of all other minds. (Ibid.: 115; emphasis added)

The emphasized phrase spells out explicitly the inherited bias, expressed by Shelley as by his forebears most rigorously in lyric composition, against mere local, temporal, circumstantial, and rational emplacement. No "partial" representation, depicting what "applies only to a definite period of time, and a certain combination of events which can never again recur," will do; the representational aim of poetry must be "universal" (ibid.). In this, at least, Shelley is in broad agreement with Samuel Johnson, a fact which perhaps more than anything suggests the power and pervasiveness of the paradigm that I have been tracing. Because the "occasional poet is circumscribed by the narrowness of his subject," Johnson $(1967$ : 20-21, 424) wrote in his Lives of the Poets, "no height of excellence can be expected from" him; "great thoughts are always general," and "sublimity" depends upon "that comprehension and expanse of thought which at once fills the whole mind, of which the first effect is sudden astonishment, and the second rational admiration." ${ }^{31}$

30. Shelley had a long-standing interest in the epistemic and ontological properties of indexicals. He $(1965,6: 196)$ writes in a similar vein as much as nine years earlier, for example, in the unfinished essay "On Life": "The words $I, y o u$, and they, are not signs of any actual difference subsisting between the assemblage of thoughts thus indicated, but are merely marks to denote the different modifications of the one mind. . . . The words . . . are grammatical devices invented simply for arrangement, and totally devoid of the intense and exclusive sense usually attached to them."

31. Shelley is closer in fact to Burke, especially in his emphasis on the means by which repre- 
Against this background, which subsumes his own typical practice (as a glance at "The Bard," "Ode on a Distant Prospect of Eton College," or "The Progress of Poesy" will show), the quiet innovation of Thomas Gray's "Elegy Written in a Country Churchyard" (1751) appears more in the character of a revolution. Even as he marks with opening allusions his indebtedness to Milton, Gray is already in the process of locating, orienting, and even to some extent embodying the borrowed and originally only typical contents:

The Curfew tolls the Knell of parting Day,

The lowing Herd winds slowly o'er the Lea,

The Plow-man homeward plods his weary Way,

And leaves the World to Darkness, and to me.

$$
(1-4)
$$

Gray's curfew bell, derived from Il Penseroso, is, like Milton's, an aural metonymy for evening and thus for an atmosphere suited to a solemn or melancholic theme; his reorientation of the plowman from L'Allegro, plodding "homeward" wearily and no longer whistlingly at the end of a day that began, in Milton's poem, "near at hand," serves an identical thematic and intertextual purpose. But Gray's representation is at the same time palpably different than Milton's, because the tolling and the plowman are individuated and spatially related within a relative frame whose coordinates, as "leaves" (a place deictic for the nonce) semantically insists, are centered on the speaker. What Milton represents as reflectively associated with a type of scene-

Oft on a Plat of rising ground, I hear the far-off Curfew sound, Over the wide-water'd shore . . .

$$
\text { (Il Penseroso 73-75)- }
$$

Gray literally re-presents as perceptually available in the immediate situationof-discourse. The sounds registered on the speaker's ear may indeed be folded together in a single sound-space, creating a pleasing imaginative harmony (the ruminative, intermittent counterpoint of the curfew knell and the lowing herd) rather than the impossible cacophony that would obtain in a spatially integrated interpretation of Milton's imagery.

Most important for our purposes is the variety and schematic clarity of

sentations focus on "the eternal, the infinite, and the one" rather than on the circumscribed and the circumstantial. Cf. Heffernan (1984: 43): "For Shelley as for Burke ... the privileged position of language is based on its special relation to the essentially immaterial world of the mind." 
the place deixis that Gray brings to the representation of the scene. All along the sequence, but with a special density in the next ten lines and toward the poem's conclusion, the speaker grounds profiled entities with reference to his location, and here the grounding terms are indisputably place deictics rather than, as so often turns out to be the case in earlier lyrics, discourse deictics. Thus, the "distan [ce]" of the "Folds" (8) and the proximity of "yonder Ivy-mantled Tow'r" (9) are construable only with reference to a proximaldistal schema whose coordinates originate at, and thus implicate, the position of the speaker. ${ }^{32}$ This same schema informs the poem's demonstratives well enough that their heads require no further determination. Contrast in this respect Gray's lines

Beneath those rugged Elms, that Yew-Tree's Shade, Where heaves the Turf in many a mould'ring Heap

$$
\left(13^{-14)}\right.
$$

with Collins's

I view that Oak, the fancied Glades among, By which as Milton lay, His Ev'ning Ear, From many a Cloud that drop'd Ethereal Dew, Nigh spher'd in Heav'n its native Strains could hear: On which that ancient Trump he reach'd was hung.

("Ode on the Poetical Character" [1747]: 63-67)

The distal specification of Gray's demonstratives is represented as sufficient for picking out the location within the situation-of-discourse of the elms and yew in question, which may then serve at once as landmarks for the prepositional location of the graveyard "beneath" them (and presumably beside "yonder . . . Tow'r" of the church, which no doubt houses the curfew bell). In Collins's poem, however, the demonstrative is primarily cataphoric rather than place deictic and points to the several post-modifications that clarify to which oak, in fact, the speaker is referring. The only spatial implication of the implicit distal schema-and it is reinforced by the term "fancied" and the preceding allusions to Milton's sublime landscape portraiture in his depiction of the "Prospect wild," "jealous Steep," and "rich ambitious Head" of Eden $(56-57,61)$ - is that the tree in question cannot be discovered here, in the speaker's situation-of-discourse. Collins's view is solely a visionary one, much like Milton's of the towers of Jerusalem in the

32. Merleau-Ponty (2004: 65) is relevant on the deictic nature of distance perception: "All my knowledge of the world, even my scientific knowledge, is gained from my own particular point of view ... I alone bring into being for myself . . the horizon whose distance from me would be abolished-if I were not there to scan it with my gaze." 
"Passion" ode. Gray's, by contrast, is distinctly grounded in a coherently schematized spatial scene that, even in the midst of the poet's meditations, is present and profilable as "this neglected Spot" (45).

I thus both agree and take issue with Charles Rzepka, who rightly characterizes Gray's "Elegy" as a watershed poem in the shift from neoclassical to romantic poetics but, as far as I can see, for all the wrong reasons. For Rzepka (1986: 2), too, the "Elegy" expresses "a certain urgency and structural coherence that is new," but he inexplicably proceeds to specify this idea not in terms of new spatial integrity but rather in terms of his central thesis of visionary solipsism, which holds the exact opposite. Here is Rzepka's (ibid.: 4) contradictory analysis of the "Elegy's" opening lines:

The transformation of something outside the mind into something inside is facilitated by the poet's having lost, in the darkness surrounding him, the tenuous conviction of his embodied being that delimits outside and inside: as the world fades out, the body vanishes. . . . The world flickers and fades, moreover, at precisely the moment that the plowman leaves it to the poet. His departure ... reinforces the feeling that the landscape is possessed solely by this mind and no other, that its existence outside the mind can no longer be independently confirmed. The departure also reinforces the reader's impression that the self has lost that sense of its finitude and outwardness, not only as a body extended in space, but as a body others can perceive, which would delimit, locate, and thus make relative rather than absolute its point of view.

I call this contradictory not only because virtually every notion hereof disembodiment, of the dissolution of internal-external locations and proximal-distal extensions, of "absolute" (intrinsic?) rather than relative framing - runs counter to my own but also because the analysis and conclusions here do not square with those Rzepka subsequently advances, often on the grounds of the same deictic evidence I'm investigating and with similar interpretive result. Take, for example, his comments about the first and last paragraphs of William Wordsworth's "Tintern Abbey":

The use of deixis . . . is pronounced throughout [the first paragraph]. "Again I hear / These waters ... Once again / Do I behold these ... cliffs," "I again repose / Here, under this dark sycamore, and view / These plots . . these orchard-tufts," "Once again I see / These hedge-rows ... these pastoral farms." The demonstrative $[\mathrm{s}] . .$. , like rhetorical gesticulations, reach toward a world out there, at hand. (Ibid: 82; note that only place deictics are emphasized.)

Here, in the final lines of "Tintern Abbey," we return to the simultaneous articulation of Other, world, and self. . . . What is to be realized in the world and preserved in another's consciousness, then, is the persistence of ... [the] self as embodied in the scene. (Ibid: 89) 
Rzepka is chiefly responding to Wordsworth's multiple specifications of the proximal field, which structure a representational search domain extending from close "at hand" to a not-too-distant "out there" and thus implicating that embodied sense of self that Rzepka is, in this instance, willing to insist upon. Certainly Gray achieves nowhere near Wordsworth's level of proximal determination, preferring instead to specify only a middle ground, in which "yonder," "those," and "that" designate points of "this neglected Spot" "here" (59) that are profiled against a background that is pointed and dimensionalized by the plowman's "leav[ing]" in a "homeward" direction and the intermittent "Tinklings" from "the distant Folds." Clearly, however, both relative and proximal-distal schemata are still in force, and Gray's careful orchestration of echoic effects - "The lowing Herd wind slowly o'er the Lea," "the Beetle wheels his droning Flight," "the moping Owl does to the Moon complain" ${ }^{33}$ - may be precisely an attempt to invoke in a muted but sustained way the corporeal schema he is not yet prepared to summon by more self-regarding and emphatically deviant deictic means.

The difference between Rzepka's and my interpretation could fittingly be characterized in terms of figure/ground relations. Against the background of Wordsworth's insistent proximity, Gray's deployment of place-deictic schemata hardly figures; recontextualized, less anachronistically, against the background of the Miltonic lyric and the poetics of the sublime, however, it suddenly stands out as innovative and compelling, not the antithesis to Wordsworth's method in the opening paragraph of "Tintern Abbey" but its important precursor. To be sure, the "Elegy" is not one sustained effort in this regard (though neither is "Tintern Abbey," as we shall see below), yet when it does proceed to the representation of its meditative as opposed to its perceptual themes, it voices not a new poetics of visionary solipsism but the old one of more or less typical associations sponsored by but in no other sense grounded in the scene. The historical approach I have charted is thus crucial to understanding not just the singular nature of Gray's achievement in the "Elegy" but, more importantly, the sea-change in spatial representation that it augurs and that will, in the romantic period, overwhelm the English lyric, forever re-proportioning its interests and objectives.

The point may be illustrated through a comparison of arguably related lines by James Thomson and William Wordsworth. The argument is James Heffernan's (1984: 11) in his fascinating and fully relevant discussion of the

33. Rzepka (1986: 125) also anticipates this argument, not in relation to Gray's poem but, rather (and less convincingly, I might add), to Coleridge's "Frost at Midnight": "sounds come at us from without, like an address, often from sources not immediately attended to, not 'kept in mind.' Sounds embrace and include: here, they help bring the poet back to the world at hand." 
"turn" in the representation of landscape from neoclassical "pictorialism to romantic engagement." ${ }^{34}$ Considering that more than two hundred editions of Thomson's The Seasons (1730/1744) had been issued by the year 180o, Heffernan (ibid.: 9-10) reasonably claims that it "probably did more than any other poem of its time to create a public taste for the poetry of landscape," typically rendered in "grand pictorial prospect" (distanced, disembodied, and intrinsic framing, in the terms of my study). Heffernan (ibid.: 18) then somewhat skeptically rehearses Wordsworth's account of his youthful awakening to an unstaked representational claim and his own poetic vocation:

Consider [Wordsworth's] description of an oak tree at sunset in An Evening Walk (written ca. 1787-89):

And, fronting the bright west in stronger lines,

The oak its dark'ning boughs and foliage twines.

(193-94)

In his seventies, Wordsworth told Isabella Fenwick that he had noticed this effect when he was a boy of fourteen or less. "The moment," he said, "was important in my poetical history; for I date from it my consciousness of the infinite variety of natural appearances which had been unnoticed by the poets of any age or country so far as I was acquainted with them; and I made a resolution to supply, in some degree the deficiency." . . . This statement has led critics to commend Wordsworth for his originality. But it tells something less than the whole truth. Specifically, it conceals the fact that by the time he wrote An Evening Walk-if not by the age of fourteen - Wordsworth was acquainted with the accounts of sunsets, especially in the poetry of Thomson. He may have discovered the darkening boughs for himself, but in writing about them in this poem, I believe that he was consciously applying a well-established method of picturesque description.

Perhaps, except that "fronting" here does seem to do peculiar place-deictic work in terms of relative spatial stationing, an effect Wordsworth amplifies by folding in the proximal-distal schema in his final revision of these lines (which, notably, Heffernan chooses not to quote): "And, fronting the

34. Heffernan (1984: 120) later characterizes this transition (quoting a distinction developed by Michael Fried in his analysis of representational strategies in French neoclassical and romantic painting) as a movement from distanced "theatricality," in which the representation is akin to "'a kind of theatrical event performed for a spectator," to a new strategy of "absorption," aiming " "to reduce to an absolute minimum all sense of distance and indeed of separateness between representation and beholder, as a step toward absorbing the beholder into the painting in an almost corporeal way." "But Fried's terms," Heffernan continues, "can also be used to explain how the English romantic poets and painters draw the beholder into their landscapes . . ." See also Barth's (2001: 53fff.) analysis of the romantic poetry of "encounter" as opposed to the eighteenth-century poetry of "reference" and "reflection." 
bright west, yon oak entwines / Its darkening boughs and leaves in stronger lines" (213-14). Since a tree has no intrinsic front, "fronting" must be construed with reference to the speaker, who, occupying a position to the east of the oak, perceives it as a figure standing out against the background of the "bright west." Its visual "front," that is, the darkening side that faces the speaker, sits at a distance "yonder" that is nevertheless close enough to allow the discrimination of the "strong" outlines of its backlit leaves. Wordsworth's claim is that he had not seen this sort of phenomenon represented in English or any other poetry he had encountered, not even-or perhaps "especially" not-in the well-known poetry of Thomson.

Conveniently enough, the first sunset that Wordsworth would have encountered in The Seasons likewise uses the adjectival "fronting" and "yon," and in a way that signals both the justice of Heffernan's generic argument and the truth of Wordsworth's personal one:

Meantime, refracted from yon eastern cloud,

Bestriding earth, the grand ethereal bow

Shoots up immense; and every hue unfolds,

In fair proportion running from the red

To where the violet fades into sky.

Here, awful Newton, the dissolving clouds

Form, fronting on the sun, thy showery prism;

And to the sage-instructed eye unfold

The various twine of light, by thee disclosed

From the white mingling maze. Not so the swain;

He wondering views the bright enchantment bend

Delightful o'er the radiant fields, and runs

To catch the falling glory; but amazed

Beholds the amusive arch before him fly,

Then vanish quite away. Still night succeeds ...

(“Spring," 203-17)

Perhaps the most important thing to observe is that all three of the place deictics here refer to grounds so distant as to lose all relative (never mind embodied) effect. The distance of the cloud indicated by "yon" must be great enough that a rainbow emanating from it could be figured as "Bestriding" the general "earth" below; and that metaphor already shifts spatial conceptualization into an intrinsic frame, in which entities are related one to another without reference to the speaker's or conceptualizer's point of view. "Here," referring to the vast scene in toto, does nothing to restore the deictic situation, nor really, or at best only to inconsiderable and illsustained effect, can "fronting." Notice that the "dissolving clouds" are represented as sitting somewhere out at the eastern horizon, facing west. 
Though clouds, like trees, have no intrinsic fronts, the very scale of Thomson's scene permits any number of orientations for the representation of what will in any case be an absolute east/west relation between clouds and sunset, a panorama that at once belittles to the point of insignificance any chosen point of view. To the question, is the imager of the given scene to the north or south of the sun's east-west arc? Thomson's lines will constrain no answer, a fact already attested by the passage's thematic representation of at least three spatially disjunct points of view on the "ethereal bow": Newton's abstract and analytical one, that of the speaker's "sage-instructed eye," and last and certainly least - no doubt because of its "amusive" relativity - that of the "enchanted" swain. To the same question about relative positioning, however, Wordsworth's lines provide a definite answer: the view can be from neither the north nor the south but must be due west and at ground level to boot.

In the Fenwick note, Wordsworth singles out these early lines because they epitomize not just a new object of representation, but, more importantly, a new way of representing such objects in lyric verse, involving (quite literally) the information of place-deictic schemata. ${ }^{35}$ Further evidence of a conscious program of representational innovation is afforded by the poems Wordsworth chose to place first and last as his contributions to the first edition of Lyrical Ballads (1798), the volume commonly credited with announcing the revolutionary poetics of English romanticism. Composed sometime between 1787 and 1795, the first, "Lines left upon a Seat in a Yew-Tree, which stands near the lake of Esthwaite, on a desolate part of the shore, commanding a beautiful prospect" (to give it its full and clearly locative title $\left.{ }^{36}\right)$, is an occasional or extempore inscription. It thus generically speci-

35. This deictic mode of representation may have been among the first of Wordsworth's influences on Coleridge, who, in representing the place specified in the title "This Lime-Tree Bower My Prison" (1797), likewise uses "fronting" as part of a rich place-deictic matrix:

Nor in this bower,

This little lime-tree bower, have I not marked

Much that has soothed me. Pale beneath the blaze

Hung the transparent foliage; and I watched

Some broad and sunny leaf, and loved to see

The shadow of the leaf and stem above

Dappling its sunshine! And that walnut-tree

Was richly tinged, and a deep radiance lay

Full on the ancient ivy, which usurps

Those fronting elms, and now, with blackest mass

Makes their dark branches gleam a lighter hue

Through the late twilight...

$(45-56)$

36. Frederick Bowers (1979: 296, 298) offers a related analysis of another Wordsworth poem about "Yew-Trees" (1811-14, published 1815): "the first fourteen lines of the poem are packed 
fies a situation-of-discourse in which the inscription and its reader are (understood to be) present, while the writer is (typically) absent. The schematic representational directives encoded by place deictics - some fourteen of them in this instance, a remarkable tally given the standards of the preceding century and a half, even in a poem of two or three hundred lines, but here compacted to powerful effect in the first forty-seven lines of a sixtyfour-line effort-are thus construed in terms of the role and location of the addressee, both of which Wordsworth figures with the poem's opening words: "Nay, Traveller!, rest. This lonely Yew-tree stands ..." Wordsworth sustains the second-person deixis throughout by sprinkling in additional vocatives and imperatives as well as a variety of pronominal references; but the spatial dimensions coordinated with this address (considered both as the discourse itself and as a location in a mental map) are oriented, specified, and to greater or lesser degree embodied in accordance with the abundant place deixis, most of which is explicitly proximal in designation or profile: "here / No sparkling rivulet"; "these barren boughs"; "these stones"; "here taught this aged Tree"; "he to the world / Went"; "these gloomy boughs"; "here he loved to sit"; "these barren rocks"; "tracing here / An emblem"; "the more distant scene"; "this deep vale"; "this seat." While still recognizable as moral emblem poem (as Wordsworth's own use of "emblem" and the wholly abstract final paragraph make clear), "Lines left upon a Seat . . ." must have struck many of its first readers as refreshingly or compromisingly delimited. Many would have wondered by what species of courtesy the inscription could be called poetry (recall Shelley's spatiotemporal distinction of the highest poetry from mere stories, above), while others might have had the satisfying recognition of a deficiency supplied.

The crucial issue of lyric sublimity, of "that comprehension and expanse of thought" that aims for "the eternal, the infinite, and the one," Wordsworth takes up, or, better, generically fully encounters, only at the volume's end, in "Lines Composed a Few Miles above Tintern Abbey, on

with grammatical gestures towards the yew trees," without which, he argues, "the poem would be wholly indefinite and lack the impact" it gains when the reader imagines him- or herself to be "in the same spatio-temporal situation as the speaker." I think Bowers's argument holds better for Wordsworth's earlier "Lines left upon a Seat . . ," for in "Yew-Trees" it is arguable that no fiction of spatiotemporal presence is intended. For example, the poem begins "There is a Yew-tree, pride of Lorton Vale, / which to this day stands single ..." As the post-modifications of "Yew-tree" imply, the tree that is "There" in "Lorton Vale" is not perceptually available but merely referenced as a topic in the speaker's situation-of-discourse. Likewise, the distal references embedded in "those fraternal Four of Borrowdale" and "there to celebrate" profile entities in a place distant not in terms of the speaker's perceptual field but rather in relation to the yew in Lorton Vale. Precisely because Wordsworth represents none of these trees as existing "in the same spatio-temporal situation as the speaker," the poem treats them more freely in terms of "Phantasy." 
Revisiting the Banks of the Wye during a Tour, July 13, 1798": a poem consciously fashioned, he (1960: 702) later said, in conformity with the "principal requisites" of the ode, especially "impassioned" transitions of thought and variety of poetic "music." The opening paragraph, as we have seen from Rzepka's analysis, uses place deixis to unite represented scene and situation-of-discourse, grounding entities in a relative reference frame, "Here, under this dark sycamore" (3), with no small degree of proximal specification and therefore (potential) embodiment. But as Heffernan (1984: 14, 171) has argued from different evidence, Wordsworth creates this vivid deictic boundary only to broach and transcend it, beginning with the very next paragraph ${ }^{37}$ Here, "These beauteous forms" of water, cliff, wood, and farm are at once anaphorically generalized for conceptual rather than perceptual handling in the ensuing lines, in which the speaker reflectively juxtaposes his immediate impressions with memories of the same landscape, what Wordsworth calls "the picture of the mind" (22). ${ }^{38}$ Mounting in abstraction and generalization through this and the next two paragraphs, the sequence at last reaches a pitch of "elevated thought" that transcends spatial boundary altogether:

a sense sublime

Of something far more deeply interfused,

Whose dwelling is the light of setting suns,

And the round ocean and the living air,

And the blue sky, and in the mind of man:

A motion and a spirit, that impels

All thinking things, all objects of thought,

And rolls through all things.

$$
\left(95^{-102)}\right.
$$

The three-paragraph sequence that rises to this comprehensive mental height presents only four (five, if one wishes to count the anaphoric but still proximal "these" at its outset) place deictics in ninety lines, and two of these determine nominals so extremely general in reference - "this unintelligible

37. Thomas McFarland (1987) argues that the poem's representational shift from objective, concrete perception to subjective, abstract reflection is underway even before the end of the first paragraph.

38. Heffernan (1984: 24-25) treats this movement in terms of temporal complication: "In Wordsworth's hands, the verbal picture becomes a means of representing time as well as space, a way of opening the eye to second sight as well as ordinary sight. . . . A landscape seen in time present revives the sight of a landscape seen in time past, and this in turn leads to the kind of vision in which we 'see into the life of things." I agree, provided we are clear that the poem nowhere attempts the direct representation of the second "sight" of the revived landscape but figures it only as explicitly mediated by and encapsulated in the speaker's reflections. 
world" and "this green earth" (40, 105) - as to nullify any spatial implications of the underlying proximal schema. Marking the poem's return from far-reaching sublimity to the circumscribed and circumstantial present, the final paragraph, in perfect balance with the opening one, contains eight specific place deictics that relocate us at the spot described at the outset, a few miles above Tintern Abbey, "here upon the banks / Of this fair river" Wye $\left(114^{-15}\right)$.

This same sequential pattern of deictic specificity framing a sublime, because spatiotemporally unmarked, meditation makes itself strongly felt in the other lyric form that Wordsworth is consciously imitating, the conversation poem of Samuel Taylor Coleridge. "The Eolian Harp" (1795), for instance, opens with a scene-setting paragraph rich in concrete imagery conveyed in terms of person and place deictics: "thy soft cheek reclined / Thus on mine arm"; "the scents / Snatched from yon bean-field"; "The stilly murmur of the distant sea tells us of silence" $(1-2,9-12)$. While only the most forward reader would assume either of the person-deictic roles, "Thus," "yon," and "distant" nevertheless function (much as the latter two do at the outset of Gray's "Elegy") to establish a relative frame of reference with foreground, mid-ground, and background specifications, each registered in terms of a distinct and schematically embodied sense. The next paragraph, by contrast, has only one person and one place deictic, both appearing in its first and clearly transitional line: "And that simplest lute, / Placed length-ways in the clasping casement, hark!" (12-13). As the exclamatory imperative already implies, a new enthusiasm possesses the speaker, and in the next twenty lines he proceeds to profile and collocate purely imaginative entities and ideas that are ungrounded in terms of the scene at hand or any other spatially determinate and coherent scene: "some coy maid" (15), ${ }^{39}$ "twilight Elfins . . . from Fairy-Land" (21-22), "birds of Paradise" (24) and, in the poem's furthest speculative reach, "the one Life within us and abroad" passage (26-33) that Coleridge added much later and that aims at the same comprehensive abstraction of reference that obtains in the "sense sublime" epiphany of "Tintern Abbey." ${ }^{0}$ The speaker's return

39. Clearly not the poem's second-person addressee, as the indefinite article and her anything but "coy" characterization in the final paragraph attest. Incidentally, "so" in line 31 , "Not to love all things in a world so filled," unlike "Thus" in line 2, is a discourse deictic, referring anaphorically to all those "things" with which the speaker has just imaginatively "filled" his mental "world."

40. See Rzepka (1986: 105-6), who argues that Coleridge here represents a "reduction of the sensorium to mental state, to thoughts and 'phantasies' that haunt the poet's passive brain [and] render the experience much like what he was to describe as a more constant, and troubling, state of mind in a letter to Sara [Coleridge, his wife] seven years later: 'I seem to exist, 
from such "plastic and vast" thoughts, in the following paragraph, is then indicated by the reintroduction of person and especially place deictics that once again index relative, proximal-distal, and (minimally) sound-sensory embodiment: "the midway slope / Of yonder hill" and "the random gales / That swell and flutter on this subject lute" $\left(34^{-35}, 42^{2-43}\right)$. Though "The Eolian Harp" continues for two more paragraphs, repeating on a smaller and now moralized scale the mental trajectory from a perceptual here to a reflective there (really, no-where) and back, Coleridge within two years has perfected the three-paragraph structure (e.g., "Reflections on Having Left a Place of Retirement" and "This Lime-Tree Bower My Prison") that both he and Wordsworth would from 1798 on expand into more various but still essentially three-part sequences. The representational structure of such poems could be roughly encapsulated by the formula spacetime ${ }_{1} \rightarrow$ sublime $_{0} \rightarrow$ spacetime $_{1}$, in which the arrows indicate simply position along the sequence and the subscripted variables indicate deictically specified (or in the case of $\mathrm{o}$, not) locations for the entities profiled in the given paragraph or passage. ${ }^{41}$

An even more striking development, however, may be seen in "A NightPiece" (1798), a brief poem in which Wordsworth contrives to fuse deictic specification and sublime transportation within a single stretch of verse. Adopting but miniaturizing the three-part sequence just described, Wordsworth gradually transforms the representation (and therefore our mental imaging) of the scene, from a distanced, intrinsic frame at the outset, to a more and more relative, proximally tethered but infinitely extensive, strangely embodied and disembodied frame at the climax, which then at the very last resolves back into a general, unspecific, and unlocated view appropriate to the meditative impulse of the final lines. Here, the central, sublime section is not the least but rather the most deictically pointed movement of the sequence. The poem may be given whole, and needs to be, because of the subtlety, variety, and cumulative force of its place-deictic effects:

- The sky is overcast

With a continuous cloud of texture close, Heavy and wan, all whitened by the Moon, Which through that veil is indistinctly seen, A dull, contracted circle, yielding light So feebly spread that not a shadow falls, Chequering the ground-from rock, plant, tree, or tower.

as it were, almost wholly within myself, in thoughts rather than in things" (emphases original). For a related discussion of this passage, see Barth 2001: 97-98.

41. Cf. Abrams (1984: esp. 103-8) on "the greater romantic lyric." 
At length a pleasant instantaneous gleam

Startles the pensive traveller while he treads

His lonesome path, with unobserving eye

Bent earthwards; he looks up - the clouds are split

Asunder, - and above his head he sees

The clear Moon, and the glory of the heavens.

There in a black-blue vault she sails along,

Followed by multitudes of stars, that, small

And sharp, and bright, along the dark abyss

Drive as she drives: how fast they wheel away,

Yet vanish not! - the wind is in the tree,

But they are silent; - still they roll along

Immeasurably distant; and the vault,

Built round by those white clouds, enormous clouds,

Still deepens its unfathomable depth.

At length the Vision closes; and the mind

Not undisturbed by the delight it feels,

Which slowly settles into peaceful calm,

Is left to muse upon the solemn scene.

$(1-26)$

Would that I had quarter- and half-shades of italics to mark the definite articles in "the pensive traveller" and "the clear Moon" as I did with "the tree," for all three noun phrases contribute to a cumulative proximal-distal effect that is only fully registered in the explicit deictics that cluster to represent the sublime moment just before "the Vision closes." As Green (1995: 121-22), Levinson (1983: 6o-61), Langacker (2002 [1994]: 33), and others have shown, the definite article typically functions in a "deictically neutral" way (Lyons 1977: 654) to pick out a contextually or referentially unique entity, that is, one that does not require any other spatiotemporal specification or support for discoursal co-reference. Nevertheless, as these same theorists proceed to argue, in some contexts the definite article does perform a pointing function, and this is certainly one of them.

The definite article that opens the poem is obviously nondeictic, determining a generic noun whose referent is, at this point, only conceptual and implicit, being concealed from perception by the focalized "overcast." In terms of construal and mental representation, this image argues for no more specific location or determinate viewpoint than somewhere on earth with a more or less vertical orientation toward an indefinite expanse of closely textured "continuous cloud," "all whitened" and therefore flattened in perspective by the backlighting of the moon. The reference of "that" in line 4 is thus principally anaphoric, and because it refers to the cloudy "veil" upon 
the sky, its distal gesture is semantically redundant and thus in no sense profiled. The next three lines first foreground a "contracted circle" of indistinct moonlight on this distant screen as a (for the moment) "feeble" but nonetheless comparatively definite point of interest and then almost at once draw our attention away and downward to the unchequered and as yet deictically unlocated "ground." The next sentence, however, now picks out a particular point of this ground, namely "the pensive traveller" and, even more specifically, the profiled span just before his feet, where he looks with "eye / Bent earthwards" upon the "lonesome path" he is "tread[ing]" and first perceives the "pleasant instantaneous gleam" that will presently reorient his (and our) attention. We can still image all of this in an intrinsic frame, but the vertical line that has been drawn from the (now opening) point in the sky above finds its footing here at a man-size point available on much nearer view, as the representation of the direction of his gaze insists. Then, bringing this nearby vertical orientation into even greater relief and beginning to invest it with deictic and relative force, Wordsworth now retraces it with three quick verbal gestures, first "up" to where "the clouds are split / Asunder," then immediately back down to the traveller's uptilted head just in the act of beholding, even as we do in the very next moment along the sequence, "The clear Moon, and the glory of the heavens." The adjective "clear" ensures that the determination of the article that precedes it is not merely anaphoric - no clear moon has yet been profiled for reference, either within the represented world or even the discourse itself-but also, to some necessary extent, place deictic.

This new force is consolidated with the first word of the next period, "There," a pronoun which refers, not anaphorically to the immediately preceding noun, "heavens," which are rather the "black-blue vault" in which the designated spot is to be located, nor to the Moon, "she," who is said to be sailing "along" or through that designated spot, but rather deictically: to the point at which the traveller is represented as looking. Having quietly but nonetheless assuredly worked us into the traveller's relative frame of reference, Wordsworth now piles on the place deictics. The most salient is surely the definite article in "the tree," which, against its own semantic categorization (see above and references), has to be construed here with a proximal specification grounded on the traveller's location that we too are by now likely to have adopted for our own imaging of the poem's representations. ${ }^{42}$ The

42. Cf. Barth (2001: 74): "We are not apart from [the speaker]; we share his experience, as he shares ours. This is surely one of the most important achievements of the poem: even though there is no first-person reference to encourage us to 'pretend' we are the poet, we feel-and increasingly so as the poem unfolds - that we are experiencing the very sensations of the traveler. We are within the experience." 
lexical contrast between sound here ("the wind is in the tree") and silence there ("But they are silent") may once again suggest sound-sensory embodiment, but in any event the near boundary specified by "the tree" is essential for the sublime crossing that presently transpires. The perspectivized line he has drawn and redrawn Wordsworth now suddenly animates and extends to infinity, depicting the motion of the stars perceived against a cloudy edge of the rift as a movement "away" into a space "immeasurably distant," yet still "deepening" "unfathomabl[y]" with the bulky dilation of "those . . . enormous" middle-ground clouds. ${ }^{43}$ The effect, engaging the mind's eye in a spatial scene that ultimately exceeds its grasp, its powers of containment and comprehension, is paradoxically realistic and visionary at once. Through a carefully choreographed series of verbal gestures, Wordsworth stretches deictic pointing beyond the limits of space-time and into the imaginative sublime.

Heffernan (1984: 170-200) gives us the apt phrase "the geometry of the infinite" to describe this representational technique, as brilliantly in force in the early "Night-Piece" as in the more famous spots-of-time that Heffernan (ibid: $121-36,156-60$ ) analyzes as well as in many other poems from all periods of Wordsworth's career. "44 "The geometry of the infinite," Heffernan (ibid.: 171-72) writes,

begins on the boundaries of the finite. Wordsworth defined the experience of sublimity as a consciousness of "immeasurable" power, and the kind of poetry that moved him most, he said once, was the poetry of "infinity ... where things are lost in each other, and limits vanish." . . Yet Wordsworth knew only too well that in order to express this feeling of limitlessness, the poet had to establishimplicitly or explicitly - the limits he was crossing. ${ }^{45}$

Perhaps no single measure captures so readily and clearly as the analysis of place deixis just how Wordsworth represents these limits and, in certain cases, even the act of crossing them that constitutes and conserves lyric sublimity. Like the skylark he so often apostrophizes and at the end of The Prelude (14.381-86) explicitly identifies with, Wordsworth too is an "Ethereal

43. The poem provides a textbook case of that "spatial extension of the finite into the infinite" which Hanke (1981: 128) sees as characteristic of the "naturalist idealist" strategy of representation: "The horizon of the phenomenal world is widened, revealing the infinite at its periphery ..."

44. See, for example, "Stepping Westward" (1805), "View from the Top of Black Comb" (1813), the solitary's sublime vision (2.829-76) in The Excursion (1814), "Composed upon an Evening of Extraordinary Splendour and Beauty" (1818), and "To the Clouds" (ca. 1842).

45. Related treatments of the thematic, philosophical, ethical, developmental, and generic dimensions of this representational method may be found in, respectively, Hartman (1964), Hanke (1981), Simpson (1982), Jonathan Wordsworth (1982), and Curran (1986). 
minstrel" who ably and routinely mounts to a deictically determined "last point of vision, and beyond" ("To a Skylark" [1825]: 7).

Keats, by contrast, draws the circle of spatial representation much more closely and thus is better emblematized by the ever-embowered nightingale, an identification he himself makes in his early epistolary lines "To George Felton Mathew" (1815:45-47) and then exploits, four years later and to much greater effect, in "Ode to a Nightingale." As my opening analysis of "This living hand" would suggest, the poems of Keats's last year of writing, and for our purposes especially the odes, might be viewed as a series of experiments in a poetics that unabashedly prioritizes the located, the relative, the proximal, and the embodied over and above - and sometimes even at the full expense of - the sublime, at least as it was traditionally understood and even recently revised. In opposition to these received senses of lyric sublimity as representation that foregoes or surpasses spatial specifications (whether through the entire disregard, the sequential foregrounding of non-perceptual themes, ${ }^{46}$ or, as in Wordsworth's most "visionary" work, the extension of perceptual themes beyond deictically determined bounds), Keats develops what might be called, adopting his own phrase, a "material sublime" that remains more or less happily within such specifications. ${ }^{47}$

The verse epistle of 1818 from which I take this phrase continues in a revealing vein:

For in the world

We jostle ...

$\ldots$ and to philosophize

I dare not yet! - Oh never will the prize,

High reason, and the lore of good and ill,

Be my award. Things cannot to the will

Be settled, but they tease us out of thought.

Or is it that imagination brought

Beyond its proper bound, yet still confined,-

Lost in a sort of purgatory blind,

46. This foregrounding is accomplished by sheer preponderance of lines in poets such as Denham, Pope, Thomson, and Collins but by three-part, climactic "centering" in poems like Gray's "Elegy" and the groundbreaking - or rather, ground-making - early romantic conversation poems and odes. Engler (1987: 70) offers a brief treatment of the same history. 47. Cf. Abrams (1998: 44): "To read him rightly, we need to recognize that [Keats] is preeminently a poet of one world, however painful his awareness of the shortcomings of that world when measured against the reach of human desire. And Keats's one world is the material world of this earth, this life, and this body ..." Lachman (2001) nevertheless argues that, at least in his episodic narratives, Keats complicates his (and our) view of this single world by playing mimetic and analogical (or discoursal) representations of space off one another. 
Cannot refer to any standard law

Of either earth or heaven? - It is a flaw

In happiness to see beyond our bourn-

It forces us in summer skies to mourn:

It spoils the singing of the nightingale.

("Dear Reynolds, as last night I lay in bed" 71-85)

Not yet of age or experience to "philosophize" in terms of "high reason" or general ethics ("the lore of good and ill"), Keats finds himself capable for the moment only of representing his embodied experience "in the world" of stubborn "things" that "tease [him] out thought." Keats clearly knows the abstract standards of lyric sublimity, but he seems here (note the transition from frustration to speculation to declaration) to be talking himself out of them and into an alternative set with respect to which imagination would stay "confined" within its "proper" earthly "bound" and would not strive "to see beyond our bourn." The resulting poetry, Keats implies (and in the following year sets out to prove), would not "mourn" in the face even of autumn skies nor "spoil" the native note of "the nightingale." 48

In this regard, consider Keats's strangely deviant use of "here" in "Ode to a Nightingale" to indicate, as Tony Bex (1995: 172) has argued, "a 'real' world and an imaginary world which have been deliberately constructed to contrast each other." For a variety of reasons, implicating the whole of the lyric history we have traced above, I think Bex and others who offer a similar reading of stanzas 3 and 4 are missing the deictic and allusive points. ${ }^{49}$ In the final lines of the second stanza, the speaker wishes:

That I might drink, and leave the world unseen, And with thee fade away into the forest dim:

Fade far away, dissolve and quite forget

What thou among the leaves hast never known, The weariness, the fever, and the fret

48. No doubt this final image refers to Coleridge's "The Nightingale: A Conversation Poem" (1798), which chastises the "night-wandering" speaker of Il Penseroso precisely for misrepresenting and thereby "spoil[ing] the singing of the nightingale." Keats's allusion thus situates his forthcoming ode in both its immediate and its more long-range literary historical contexts. It also implies that his too will be a bold and explicit revision of this cumulative lyric inheritance.

49. See, e.g., McFarland (1985: 141-42): "John Keats sits at his table. That is primary imagination. He creates a poem in which he dwells as poet with aching heart. That is the secondary imagination. Then he dissolves a world he has expanded by secondary imagination, and creates a secondary world reached by viewless wings from within the poem already in existence. That is a secondary extension of secondary imagination." Rzepka (1986: 175) gives a similar reading. 
Here, where men sit and hear each other groan;

Where palsy shakes a few, sad, last gray hairs,

Where youth grows pale, and spectre-thin, and dies;

Where but to think is to be full of sorrow

And leaden-eyed despairs,

Where Beauty cannot keep her lustrous eyes,

Or new Love pine at them beyond tomorrow.

4

Away! Away! for I will fly to thee,

Not charioted by Bacchus and his pards,

But on the viewless wings of Poesy,

Though the dull brain perplexes and retards:

Already with thee! tender is the night,

And haply the Queen-Moon is on her throne,

Cluster'd around by all her starry Fays;

But here there is no light,

Save what from heaven is with the breezes blown

Through verdurous glooms and winding mossy ways.

$$
(19-40)
$$

The occasion of the poem, in fiction as well as fact,$^{50}$ is the proximal presence of a nightingale that in "some melodious plot / Of beechen green, and shadows numberless, / Singest of summer in full-throated ease" (810). The first "here" the speaker designates is not so much the location he occupies in aural vicinity of the nightingale but rather, and without any proximal specification whatsoever, the "sad" "world" of human suffering and mortality, "but to think" of which threatens to "spoil the singing of the nightingale." The strong desire to flee this conceptual world of woe underlies the speaker's deictic conceptualization of a space farther "away" from his present location, deeper and more distant in "the forest dim" than the shadowy grove the nightingale inhabits nearby. To this distal realm, the speaker presently flies on his "viewless wings of Poesy" and thus designates it in stanza 4 as "here." But in no respect other than horizontal distancea parameter which is itself at least nominally collapsed-is this imagined realm different from or transcendent to the actual physical location of the speaker in the represented situation-of-discourse, which is after all not a scene of disease and death but a portion of "some melodious plot" in nature,

50. See Keats's Complete Poems (1978: 468), in which Stillinger reproduces Charles Brown's account of the "circumstances of composition":

In the spring of 1819 a nightingale had built her nest near my house. Keats felt a tranquil and continual joy in her song; and one morning he took his chair from the breakfast-table to the grass-plot under a plumtree, where he sat for two or three hours. When he came into the house, I perceived he had some scraps of paper in his hand. 
not quite as deep in "verdurous gloom" as the imaginative bourn perhaps but, considering the necessarily proximal "beechen green, and shadows numberless," not so very far from it. Thus, the world of imagination has hardly been constructed, as Bex would have it, in "deliberate . . contrast" to the "real world" of the discourse situation. Jack Stillinger (1971: 91, 106) argues instead, to my mind rightly, that "the speaker would fade away with the bird, and forget ... the mortal world. . . . But when he imaginatively joins the bird in the forest, he immediately longs for the world he has just rejected"; he therefore renders the imaginative world in "a series of lovingly detailed images drawn from memory of the transient natural world he has left behind." Helen Vendler (1983: 85) concurs: "The vulnerability of the bower to time - at least to the cyclical rhythms of the vegetative cycle of fading violets and coming roses - prevents it offering any real escape from the world 'where youth grows pale, and spectre-thin, and dies." And this modeling of the distal realm upon the proximal one is signaled, I would add, in Keats's deliberately challenging use of "here," which already ironically inscribes the poem's "forlorn" conclusion that "fancy cannot cheat so well / As she is famed to do" $(71,73-74) .^{51}$

This reading is strengthened when we consider Keats's quite literal subversion of the Miltonic sources that inform his depiction of the nightingale's bower. Keats's "viewless wings of Poesy" are borrowed from the final stanza of the "Passion" ode, where the speaker hypothetically "hurrie[s] on viewless wing" from Christ's sepulcher to the generalized tops of "Mountains wild," from whence "Echoes" of his lamentation would resound through the wide "neighborhood of grove and spring" and into the "cloud[s]" (50-56). Significantly, Milton's imagery amplifies outward and upward, toward the unbounded heavens; Keats's speaker, in marked contrast, flies to a mimetic

51. Critics generally prefer to read this and any ode as a process of thought rather than a product of thought, but this is to accept uncritically the fiction at the expense of the fact. Though Keats may represent his speaker as discovering only at the end of the ode that fancy is a "deceiving elf," the poet himself knew it well before he ever started the poem, as a sonnet from three years earlier attests:

Oh! how I love, on a fair summer's eve,

When streams of light pour down the golden west,

And on the balmy zephyrs tranquil rest

The silver clouds, far-far away to leave

All meaner thoughts, and take a sweet reprieve

From little cares: - to find, with easy quest,

A fragrant wild, with Nature's beauty drest,

And there into delight my soul deceive.

("Oh! how I love ..." 1-8)

So much here anticipates "Ode to a Nightingale": "far-far away," "deceive," the notion of leaving "meaner thoughts" and "little cares" behind through an "easy quest" to a "fragrant wild, with Nature's beauty drest"; see also line 12 of the sonnet: "on the wing of poesy upsoar." 
space confined between the flower-strewn ground "at my feet" and the incense-laden boughs "hang[ing]" near his head (41-42). This is no gesture of Miltonic lyric sublimity but rather an ironic circumscription of imagination within the narrowest bodily and natural limits. No less ironic is Keats's use of "Darkling" (51), drawn from the proem to Book 3 of Paradise Lost, where Milton describes his nightly inspiration by Urania, "the heav'nly Muse," and compares himself to the nightingale, "the wakeful Bird" that "Sings darkling, and in shadiest Covert hid / Tunes her nocturnal Note" (19,

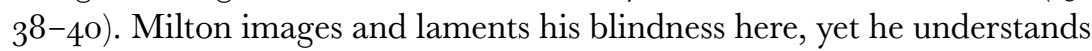
that it paradoxically qualifies him for the task he is about to commence, the representation of "things invisible to mortal sight," the "Celestial light" of God and heaven $(51,55)$. Keats's lines "I cannot see," "here there is no light / Save what from heaven is with the breezes blown," and "Darkling I listen" are thus essentially parodic and underscore his refusal to aspire beyond the "bourn" of nature or, more precisely, imagination's actual and embodied, if not traditionally "proper," bound, here - "in the world" that, in the end, one departs only to become (as stanza 3 is already too aware, and stanza 6 again confirms) "a sod" (6o). ${ }^{52}$

Thus, rather than opposing imagination (i.e., the represented situation within the discourse) and reality (i.e., the situation in which the discourse unfolds), Keats appears to be knowingly conflating the two and confining them within narrowly and naturally determined proximal bounds. ${ }^{53}$ To the

52. Even this mortal note infusing the scene of imagination is borrowed from Milton. Keats's catalog of flowers in stanza 5 , leading directly to the re-profiling of the theme of death in stanza 6, is imitated from a similar catalog in Milton's elegy Lycidas (cf. 134-51). Note that Milton concludes his catalog with a sentiment quite similar to Keats's about fancy as a "deceiving elf": "For so to interpose a little ease, / Let our frail thoughts dally with false surmise" $\left(15^{2-53)}\right.$. But note likewise that Keats essentially ends his poem here, well short of the transcendental consolation to which Milton's sublimely proceeds.

While Keats's flowers have their literary antecedents, they also, interestingly enough, correspond to natural and perceptual events at and around the time of composition. Stillinger (Keats 1978: 468) suggests composition in May 1819, but since the poem was not published until July, Keats could have been tinkering with it until then. In a letter of early May, Keats (1952: 341), anticipating the ode's ideas of "fading violets" and "coming musk-roses" (47, 49), writes, "this is the 3 rd of May and everything is in delightful forwardness; the violets are not withered, before the peeping of the first rose." In another letter, from early July, he writes of nearby cottages being "covered with creepers and honeysickles[,] with roses and eglantines peeping in at the windows" (ibid.: 354). The "pastoral eglantine" appears in the "Ode" but not in Lycidas, and though Milton lists many more varieties of flowers than does Keats, Keats's "White hawthorn" (46) is not among them. These coincidences bolster the argument that Keats is consciously confining his lyric inheritance within naturally determined bounds. 53. Noting "the incomprehensible dissolution of oppositions that has occurred throughout the progress of the poem," Curran (1986: 82) asks: "How can Keats divide 'here' and 'there' so insistently in the poem, only to find not simply their interdependence but their actual superimposition on the same ground?" Curran focuses his own answer in generic terms, suggesting 
extent that the two situations are images of phenomenally if not ontologically similar conditions, the poem's final questions - "Was it a vision, or a waking dream? / . . . Do I wake or sleep?” (79-8o)-may register a distinction without a perceptible difference. For the space that Keats represents at last, and with especially compelling deictic determination, simply uncouples on a horizontal trajectory traced by place deixis the two locations that, in terms of construal, were challengingly collapsed in stanza 4's highly profiled reference to "here": "Adieu! adieu! thy plaintive anthem fades / Past the near meadows, over the still stream, / Up the hill-side; and now 'tis buried deep / In the next valley-glades: / Fled is that music" $\left(75^{-78}, 80\right)$. The speaker tracks the nightingale by its fading anthem as it departs from the relatively proximal "melodious plot" where it has been stationed throughout the poem and flies away over "near meadows" and a farther hillside to drop into a remote glade or "forest dim" on the hill's other side. He thus holds our attention irresistibly to the contours of the earth as he directs it to a point not of visionary liberation but rather of imaginative vacuity. ${ }^{54}$ The lyric imagination is here "buried deep" at a bourn or limit that Keats's representation pretends neither to penetrate nor to transcend.

Keats's refusal to project a sublime lyric space beyond the bounds of his place-deictic determinations is no less evident in "Ode on a Grecian Urn," which again collapses the distinction between the immediate and the imaginative by using the proximal-distal schema in a peculiarly confining way. The first stanza establishes a relative view on the urn within the situation-of-discourse, with the speaker verbally pointing to its proximal surface imagery: "What men or gods are these?" (8). It is possible to interpret the second stanza as reconceiving the same imagery in terms of a different relative frame anchored now within the urn's represented situation and adopting its proximal-distal determinations, concerning, for example, "those trees" that will never "be bare" (16). ${ }^{55}$ The fourth stanza, however,

that Keats's "superimposition" of traditional antitheses undoes the dialectical form and ideology of the ode. Sheats (1990: 194) agrees: "As [Keats] imagines the sky he cannot see, in the only explicit upward gesture of attention in the ode, he could be said to dramatize the withdrawal of the poem from the generic norm. ... [The] imagined 'Queen-Moon' and her court of Fays seem prettily decorative, reduced by 'haply' to the hypothetical, in comparison to the intense monosyllabic empiricism of the short line: 'But here there is no light.' The distance between this 'here' and the 'there' it implies is partly generic: it measures the difference between this ode and the traditional decorum of the greater ode, from which it here diverges forcefully."

54. Rzepka (1986: 178) makes a similar point.

55. Some such construction seems to inform Wasserman's (1953: 30-31) reading of the poem as "the drama of the poet's absorption" into the urn, his "empathetic movement . . from consideration of the urn as total object to participation in the inwardness of [its] symbols ..." 
shows that Keats has no such dislocation in mind but is rather marking, from the poem's first and only point of view, the minute distances between one relief and another. Thus, "those trees" simply appear to be behind the "men or gods" that are foregrounded upon the urn, just as "that heifer" is located farther back on the urn's curvature than "these coming to the sacrifice" $(33,31)$. In other words, the place deixis of the ode consistently embodies a situation-of-discourse in which the speaker, as in a museum, ponders an object before him. As in stanza seven of "Ode to a Nightingale," but even more emphatically here, when his vision attempts to extend from the immediately perceptible to an imagined beyond, from "this folk" of celebrants to either the unrepresented "little town" they must, in the urn's represented world, be processing from or the unrepresented "altar" they must be processing to, his conception halts, baffled and forlorn, on the verge of such "emptied," "silent," and "desolate" conceptual prospects (37-40). Thus "tease[d] . . . out of thought" by the impenetrable philosophical and aesthetic issues of (a) representation's origin and end, ${ }^{56}$ the speaker of "Ode on a Grecian Urn" equably returns his attention and ours to the sole and specific dimensions, here and now, of the poem's situation-of-discourse, in which "all / [W]e know on earth, and all [w]e need to know," appears (44, $49-50) .{ }^{57}$

56. Lachman (2001: 105, 112) analyzes similar mimetic truncations in Keats's Hyperion that "run counter to our expectation of order in life and in narrative: the [poem's] sudden beginning plays on our ignorance of all that preceded it, while [its] abrupt point of closure leaves the reader in the dark about the future." These and other tactics ensure that the traditional narrative focus on represented "time-space is subordinated to the movement of perspective" along the sequence.

57. Cf. Lundeen (1995: 107): "The urn succeeds as art (by virtue of its inscrutability) but fails to provide Keats with an alternative to the spatio-temporal scheme in which he is trapped." Even the odes addressed to more abstract, allegorical, and mythical subjects profile the situationof-discourse as opposed to other possible and more sublime scenes. The speaker of "Ode to Melancholy," collapsing the conceptual distinctions between Milton's L'Allegro and Il Penseroso, "go[es] not" to seek "Veil'd Melancholy" in mythical Lethe or through sense-stifling charms but, rather, discovers her more immediate habitation in "aching Pleasure[s] nigh" (1, $23,26)$. In the "Ode on Indolence," the insistent invocation of the proximal schema through genuine deictics and deictics-for-the-nonce, such as "passed," "came," "return," and "away" $(5,7-8,14)$, creates the illusion of a narrowly confined space in which the speaker again appears naturally embowered, "cool-bedded in the flowery grass" (52). In "Ode to Psyche," the most rigorously abstract of the odes (see Vendler 1983: 47ff.) and by far the most Miltonic of the lot (cf. the ode "On the Morning of Christ's Nativity" [1629], to which Keats alludes repeatedly and comparatively unironically), place deixis appears with density and effect only in the final stanza's description of the mental "fane" that the speaker means to build for the rites and worship of the goddess Psyche. Notably, it is distal deixis - "those darkcluster'd trees," "there by zephyrs, streams, and birds, and bees" - which, in keeping with the modals "will" and "shall" in every clause of the stanza, indicates that the imagined bower is merely projected and not yet constructed. The speaker remains, as it were, here, in a world outside the still "untrodden region[s]" of his mind $(50-51,54,56-57$, etc.). 
These strategies in the use of place deixis effectively write the elegy (pardon the pun) on sublimity in the English lyric, at least of the spacetranscending kind ${ }^{58}$ Against what he terms the foreign and "artful" ambitions of the Miltonic-Wordsworthian sublime, Keats (1952: 384, 390-91) in the fall of 1819 theorizes a fully indigenous and natural approach to representation, "agrestunal" and "sylvestran" as he terms it, which would provide access to "other" - because unwaveringly relative, local, and embodied"sensations." Literally within days, Keats pens "To Autumn," a poem that expresses his "sensory ideology" (Hartman 1975: 140) to perfection, though here without the use of a single categorical place deictic. In response to this surprising freedom, Kathleen Lundeen (1995: 112) has argued that the poem "evaporates the parameter of distance": "There ceases to be a 'there,' and a sense of delimiting space disappears. The absence of a fixed vantage point apart from the subject signals the disappearance of self-consciousness and, consequently, space consciousness as well." But "apart from the subject" is a crucial qualification, and surely Vendler's (1983: 244-45) contrasting argument of the poem's "meticulous topography," its "concentric plottings of space" "expand[ing] from cottage to horizon," is more accurate, or at least more precisely articulated. Space consciousness does not disappear here; on the contrary, it is "the unmoving center from which all is seen and heard," "a pure immersion in the actual" (ibid.: 254, 261) so indisputably located that it references entities within a spatially coherent scene with transparent - that is, entirely non-deictic and unprofiled-ease. Most significantly, as the speaker's view extends outward from "the thatch-eaves" and "moss'd cottage trees" of the first stanza to the "barred clouds" and "gathering swallows ... in the skies" of the last $(4-5,25,33)$, it describes a trajectory that is bounded at the horizon and vertically foreshortened by the profiled swallows, whose airy "gathering" or clustering seems to cap the view and, literally, the extent of interest. Even where the poem treats evidently emblematic and certainly memorial themes, as in the middle stanza, these are fitted to the relative and proximal-distal schemata governing the poem (and the corporeal one too, considering the always operative sound symbolism) and depict middle-distance views of "granary," "furrow," and "brook" (14, 16, 20). Though a personified season is the addressee and obviously ontologically dissimilar to, say, the "gourd," "cider-press," and "hedge-crickets" that are associated with it $(7,21,31)$, this purely conceptual theme is repre-

58. An important exception is Tennyson, who in his own great elegy, In Memoriam, works new but nevertheless nostalgic variations on the Wordsworthian sublime. The major development after Keats, insofar as the fully situational use of place deixis is concerned, comes in the dramatic monologue of Robert Browning and its subsequent reformulations in the hands of the modernists. 
sented in terms of a prevailing perceptual order and is incorporated in the sequence without being profiled or prioritized in any way - as it would be, one way or another, in a setting by Milton, Denham, Thomson, Collins, Gray, and countless others, including, in most instances, even Coleridge or Wordsworth and certainly Shelley. With "To Autumn" the greater English lyric becomes fully and, judging by subsequent developments, irrevocably placed.

\section{References}

Abrams, M. H.

1984 The Correspondent Breeze: Essays on English Romanticism (New York: W. W. Norton). 1998 "Keats's Poems: The Material Dimensions," in The Persistence of Poetry: Bicentennial Essays on Keats, edited by Robert Ryan and Ronald Sharp, 36-53 (Amherst: University of Massachusetts Press).

Addison, Joseph, and Richard Steele

1945 [1712] The Spectator, edited by Gregory Smith, 4 vols. (London: J. M. Dent).

Barth, J. Robert, S.J.

2001 The Symbolic Imagination: Coleridge and the Romantic Tradition, 2nd ed. (New York: Fordham University Press).

Bex, Tony

1995 "Keats and the Disappearing Self: Aspects of Deixis in the Odes," in New Essays in Deixis: Discourse, Narrative, Literature, edited by Keith Green, 16o-178 (Amsterdam: Rodopi).

Bowers, Frederick

1979 "Reference and Deixis in Wordsworth's 'Yew Trees,'" English Studies in Canada 5 (3): 292-300.

Brisard, Frank

2002 "Introduction: The Epistemic Basis of Deixis and Reference," in Grounding: The Epistemic Footing of Deixis and Reference, edited by Frank Brisard, xi-xxxiv (Berlin: Mouton de Gruyter).

Burke, Edmund

1990 [1757] A Philosophical Enquiry into the Origin of Our Ideas of the Sublime and Beautiful, edited by Adam Phillips (Oxford: Oxford University Press).

Campbell, John

1993 "The Role of Physical Object in Spatial Thinking," in Spatial Representation: Problems in Philosophy and Psychology, edited by Naomi Eilan, Rosaleen McCarthy, and Bill Brewer, 65-95 (Oxford: Oxford University Press).

Chambers, Douglas

1996 The Reinvention of the World: English Writing 1650-1750 (London: Arnold).

Coleridge, Samuel Taylor

1912 Poetical Works, edited by Ernest Hartley Coleridge (Oxford: Oxford University Press).

Collins, William

1961 [1919] The Poems of Gray and Collins, edited by Austin Lane Poole (London: Oxford University Press).

Culler, Jonathan

1981 The Pursuit of Signs: Semiotics, Literature, Deconstruction (Ithaca, NY: Cornell University Press).

Curran, Stuart

1986 Poetic Form and British Romanticism (New York: Oxford University Press). 
Denham, John

1969 [1908] The Poetical Works of John Denham, edited by Theodore Howard Banks (New York: Archon Books).

Engler, Balz 1987 "Deictics and the Status of Poetic Texts," in The Structure of Texts, edited by Udo Fries, 65-73 (Tübingen: Gunter Narr Verlag).

Gillies, John

2001 "The Scene of Cartography in King Lear," in Literature, Mapping, and the Politics of Space

in Early Modern Britain, edited by Andrew Gordon and Bernhard Klein, 109-37 (Cambridge: Cambridge University Press).

Gray, Thomas

1966 The Complete Poems of Thomas Gray, edited by H. W. Starr and J. R. Hendrickson (Oxford: Clarendon).

Green, Keith

1992 "Deixis and the Poetic Persona," Language and Literature 1 (2): 121-34.

Hanke, Amala M.

1981 Spatiotemporal Consciousness in English and German Romanticism: A Comparative Study of Novalis, Blake, Wordsworth, and Eichendorff(Berne: Peter Lang).

Hartman, Geoffrey $\mathrm{H}$.

1964 Wordsworth's Poetry, 1787-1814 (New Haven, CT: Yale University Press).

1975 The Fate of Reading and Other Essays (Chicago: University of Chicago Press).

Heffernan, James A. W.

1984 The Recreation of Landscape: A Study of Wordsworth, Coleridge, Constable, and Turner (Hanover, NH: University Press of New England).

Herman, Vimala

1997 "Deixis and Space in Drama," Social Semiotics 7 (3): 269-83.

1999 "Deictic Projection and Conceptual Blending in Epistolarity," Poetics Today 20: 523-41.

Ingarden, Roman

1973 [1965] The Literary Work of Art: An Investigation on the Borderlines of Ontology, Logic, and

Theory of Literature, translated by George G. Grabowicz (Evanston, IL: Northwestern University Press).

Johnson, D. Barton

1982 "Spatial Modeling and Deixis: Nabokov's Invitation to a Beheading," Poetics Today 3 (1): 81-98.

Johnson, Samuel

1967 The Lives of the English Poets, edited by George Birkbeck Hill, vol. 1 (New York:

Octagon).

Keats, John

1952 The Letters of John Keats, edited by Maurice Buxton Forman (London: Oxford University Press).

1978 Complete Poems, edited by Jack Stillinger (Cambridge, MA: Harvard University Press).

Lachman, Lilach

2001 "Keats's Hyperion: Time, Space, and the Long Poem," Poetics Today 22: 89-127.

Lamb, Jonathan

1997 "The Sublime," in The Cambridge History of Literary Criticism, vol. 4, edited by H. B.

Nisbet and Claude Rawson, 394-416 (Cambridge: Cambridge University Press).

Langacker, Ronald W.

2002 [1994] "Remarks on the English Grounding Systems," in Grounding: The Epistemic Foot-

ing of Deixis and Reference, edited by Frank Brisard, 29-37 (Berlin: Mouton de Gruyter).

Lenz, Friedrich

2003 "Introduction," in Deictic Conceptualization of Space, Time, and Person, edited by Friedrich

Lenz, vii-xiv (Amsterdam: John Benjamins). 
Levinson, Stephen C.

1983 Pragmatics (Cambridge: Cambridge University Press).

2003 Space in Language and Cognition: Explorations in Cognitive Diversity (Cambridge: Cambridge University Press).

Lundeen, Kathleen 1995 "Keats's Post-Newtonian Poetics," Keats-Shelley fournal 44: 102-16.

Lyons, John

1977 Semantics, 2 vols. (Cambridge: Cambridge University Press).

McFarland, Thomas

1985 Originality and Imagination (Baltimore, MD: Johns Hopkins University Press).

1987 "Wordsworth's Hedgerows: The Infrastructure of the Longer Romantic Lyric," in The Age of William Wordsworth: Critical Essays on the Romantic Tradition, edited by Kenneth R. Johnston and Gene W. Ruoff, 239-58 (New Brunswick, NJ: Rutgers University Press).

Merleau-Ponty, Maurice

2004 Basic Writings, edited by Thomas Baldwin, translated by C. Smith, revised by F. Williams (London: Routledge).

Milton, John

1957 Complete Poems and Major Prose, edited by Merritt Y. Hughes (Indianapolis, IN: Odyssey).

Rauh, Gisa

1983 "Aspects of Deixis," in Essays on Deixis, edited by Gisa Rauh, 9-6o (Tübingen: Gunter Narr).

Richardson, Alan

2001 British Romanticism and the Science of the Mind (Cambridge: Cambridge University Press).

Rzepka, Charles J.

1986 The Self as Mind: Vision and Identity in Wordsworth, Coleridge, and Keats (Cambridge, MA:

Harvard University Press).

Sheats, Paul D.

1990 "Keats, the Greater Ode, and the Trial of Imagination," in Coleridge, Keats, and the Imagination: Romanticism and Adam's Dream, edited by J. Robert Barth and John L. Mahoney, 174-200 (Columbia: University of Missouri Press).

Shelley, Percy Bysshe

1965 The Complete Works of Percy Bysshe Shelley, edited by Roger Ingpen and Walter E. Peck, 10 vols. (New York: Gordian).

Simpson, David

1982 Wordsworth and the Figurings of the Real (Atlantic Highlands, NJ: Humanities Press).

Sternberg, Meir

1981 "Ordering the Unordered: Time, Space, and Descriptive Coherence," Yale French Studies 61: 60-88.

1983 "Deictic Sequence: World, Language, and Convention," in Rauh 1983: 277-316.

1990 "Telling in Time (I): Chronology and Narrative Theory," Poetics Today 11: 901-48.

1992 "Telling in Time (II): Chronology, Teleology, Narrativity," Poetics Today 13: 463-541.

Stillinger, Jack

1971 The Hoodwinking of Madeline and Other Essays on Keats's Poems (Urbana: University of Illinois Press).

Thomson, James

1908 The Complete Poetical Works of Fames Thomson, edited by J. Logie Robertson (London:

Oxford University Press).

Tracy, Rosemarie

1983 "Cognitive Processes and the Acquisition of Deixis," in Rauh 1983: 99-148.

Vendler, Helen

1983 The Odes of John Keats (Cambridge, MA: Harvard University Press). 
Wasserman, Earl R.

1953 The Finer Tone: Keats'Major Poems (Baltimore, MD: Johns Hopkins University Press). Werner, Steffen, Christina Saade, and Gerd Lüer

1998 "Relations between the Mental Representation of Extrapersonal Space and Spatial Behavior," in Spatial Cognition: An Interdisciplinary Approach to Representing and Processing Spatial Knowledge, edited by Christian Freska, Christopher Habel, and Karl F. Wander, 107-28 (Berlin: Springer).

Wordsworth, Jonathan

1982 William Wordsworth: The Borders of Vision (Oxford: Clarendon).

Wordsworth, William

196o Poetical Works of William Wordsworth, edited by Thomas Hutchinson, revised by Ernest de Selincourt (London: Oxford University Press). 
Copyright of Poetics Today is the property of Duke University Press. The copyright in an individual article may be maintained by the author in certain cases. Content may not be copied or emailed to multiple sites or posted to a listserv without the copyright holder's express written permission. However, users may print, download, or email articles for individual use. 